\title{
Latitudinal and temporal distributions of diatom populations in the pelagic waters of the Subantarctic and Polar Frontal zones of the Southern Ocean and their role in the biological pump
}

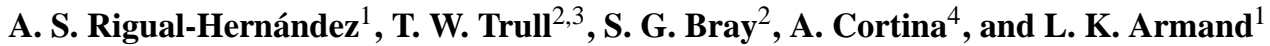 \\ ${ }^{1}$ Department of Biological Sciences, Macquarie University, North Ryde, NSW 2109, Australia \\ ${ }^{2}$ Antarctic Climate and Ecosystems Cooperative Research Centre, University of Tasmania, Hobart, Tasmania 7001, Australia \\ ${ }^{3}$ CSIRO Oceans and Atmosphere Flagship, Hobart, Tasmania 7001, Australia \\ ${ }^{4}$ Department of Environmental Chemistry, IDAEA-CSIC, 08034 Barcelona, Spain
}

Correspondence to: A. S. Rigual-Hernández (andres.rigualhernandez@mq.edu.au)

Received: 18 May 2015 - Published in Biogeosciences Discuss.: 11 June 2015

Accepted: 30 August 2015 - Published: 17 September 2015

\begin{abstract}
The Subantarctic and Polar Frontal zones (SAZ and PFZ) represent a large portion of the total area of the Southern Ocean and serve as a strong sink for atmospheric $\mathrm{CO}_{2}$. These regions are central to hypotheses linking particle fluxes and climate change, yet multi-year records of modern flux and the organisms that control it are, for obvious reasons, rare. In this study, we examine two sediment trap records of the flux of diatoms and bulk components collected by two bottom-tethered sediment traps deployed at mesopelagic depths $(\sim 1 \mathrm{~km})$ in the SAZ (2-year record; July 1999-October 2001) and in the PFZ (6-year record; September 1997-February 1998, July 1999-August 2000, November 2002-October 2004 and December 2005-October 2007 ) along the $140^{\circ}$ E meridian. These traps provide a direct measure of transfer below winter mixed layer depths, i.e. at depths where effective sequestration from the atmosphere occurs, in contrast to study of processes in the surface ocean. Total mass fluxes were about twofold higher in the PFZ $\left(24 \pm 13 \mathrm{~g} \mathrm{~m}^{-2} \mathrm{yr}^{-1}\right)$ than in the SAZ $\left(14 \pm 2 \mathrm{~g} \mathrm{~m}^{-2} \mathrm{yr}^{-1}\right)$. Bulk chemical composition of the particle fluxes mirrored the composition of the distinct plankton communities of the surface layer, being dominated by carbonate in the SAZ and by biogenic silica in the PFZ. Particulate organic carbon (POC) export was similar for the annual average at both sites $\left(1.0 \pm 0.1\right.$ and $0.8 \pm 0.4 \mathrm{~g} \mathrm{~m}^{-2} \mathrm{yr}^{-1}$ for the PFZ and SAZ, respectively), indicating that the particles in the SAZ were relatively POC rich. Seasonality in the particle export was more pronounced in the PFZ. Peak fluxes occurred during summer
\end{abstract}

in the PFZ and during spring in the SAZ. The strong summer pulses in the PFZ are responsible for a large fraction of the variability in carbon sequestration from the atmosphere in this region. The latitudinal variation of the total diatom flux was found to be in line with the biogenic silica export with an annual flux of $31 \pm 5.5 \times 10^{8}$ valves $\mathrm{m}^{-2} \mathrm{yr}^{-1}$ at the PFZ compared to $0.5 \pm 0.4 \times 10^{8} \mathrm{~m}^{-2} \mathrm{yr}^{-1}$ at the SAZ. Fragilariopsis kerguelensis dominated the annual diatom export at both sites (43\% at the SAZ and $59 \%$ in the PFZ). POC fluxes displayed a strong positive correlation with the relative contribution of a group of weakly silicified and bloom-forming species in the PFZ. Several lines of evidence suggests that the development of these species during the growth season facilitates the formation of aggregates and carbon export. Our results confirm previous work suggesting that $F$. kerguelensis plays a major role in the decoupling of the carbon and silicon cycles in the high-nutrient low-chlorophyll waters of the Southern Ocean.

\section{Introduction}

The Southern Ocean is a critical component of the Earth's ocean-climate system and plays a pivotal role in the global biogeochemical cycles of nutrients and carbon. Due to its unique meridional overturning circulation, deep waters are upwelled south of the polar front supplying the surface waters with nutrients and allowing the ventilation of carbon 
dioxide accumulated during centuries of deep-sea respiration (Anderson et al., 2002; Pollard et al., 2006). Strong interactions with the atmosphere transform the upwelled deep waters into bottom, intermediate, and mode waters, which spread to lower latitudes renewing the intermediate and abyssal depths of the world ocean (Sarmiento et al., 2004; Sigman et al., 2010). Dissolution of carbon dioxide in these newly formed waters (i.e. the solubility pump) and the transport of photosynthetically fixed carbon to depth in settling particles (i.e. the biological pump) modulate the extent to which the carbon dioxide is transferred to the atmosphere. The balance between these processes determines the role of the Southern Ocean either as a source or sink of atmospheric $\mathrm{CO}_{2}$ over glacial-interglacial climate cycles (Kohfeld et al., 2005; Anderson et al., 2009; Sigman et al., 2010).

At present, the Southern Ocean biological pump is not operating at its full capacity (De La Rocha, 2010). Low sun angles, deep wind-mixed surface waters and lack of the micronutrient iron restrict phytoplankton growth (Boyd et al., 2007; Venables and Moore, 2010) making the Southern Ocean the largest high-nutrient low-chlorophyll (HNLC) region in the world ocean (Martin, 1990). However, there are exceptions to this situation with areas of higher phytoplankton abundance occurring along oceanographic fronts (Laubscher et al., 1993; Moore and Abbott, 2000), downstream of some islands (Blain et al., 2001; Park et al., 2010), in the wake of the retreating seasonal sea ice (Smith Jr. et al., 1988; Brzezinski et al., 2001), in coastal polynyas (Arrigo and van Dijken, 2003) and in coastal systems of Antarctica (Sedwick et al., 2000; Brzezinski et al., 2001). In these areas iron fertilises the surface layer triggering phytoplankton blooms in spring and summer.

Diatoms are one of the most abundant primary producers in the Southern Ocean and make a major contribution to the biogenic silica (BSi) content of deep-sea sediments. Extensive diatom blooms occasionally develop in the Antarctic Circumpolar Current (ACC; e.g. Kopczynska et al., 2001; Green and Sambrotto, 2006; Alvain et al., 2008; Grigorov et al., 2014) which results in the formation of a band of siliceous ooze that encircles Antarctica (DeMaster, 1981; Buesseler et al., 2001; DeMaster, 2002). This "diatom ooze belt" constitutes the world's largest sedimentary sink for BSi accounting for about one-third of the global BSi accumulation (Tréguer and De La Rocha, 2013; Tréguer, 2014). Therefore, the production and export of diatoms in the Southern Ocean are critical components of the global cycling of silica, and potentially the biological carbon pump. Indeed there is evidence from silicon isotopes and other palaeo-proxies that silica export in the Southern Ocean has varied, in concert with other biogeochemical changes and atmospheric $\mathrm{CO}_{2}$ variations, over a range of timescales (Brzezinski et al., 2002; Matsumoto et al., 2002; Sarmiento et al., 2004).

Most of our current knowledge about the temporal and spatial dynamics of phytoplankton in the Southern Ocean waters derives from satellite observations and biogeochemi- cal models (e.g. Moore et al., 1999; Moore and Abbott, 2000; Arrigo et al., 2008; Gregg and Rousseaux, 2014). Recently, advances in the interpretation of optical signals have allowed the determination of the specific contribution of major phytoplankton groups (e.g. coccolithophores, phaeocystis-like, diatoms) to phytoplankton abundance on a global and regional scale (e.g. Alvain et al., 2005; Raitsos et al., 2008; Rousseaux and Gregg, 2012; Alvain et al., 2013). However, as a more complete picture of the structure of the planktonic communities emerges, it becomes evident that in order to determine the role of phytoplankton in the biological pump and biogeochemical cycles, it is of critical importance to distinguish not just among major taxonomic groups but also within them. In particular, recent studies have shown how variations in the composition of diatom communities, which exhibit a wide range of competitive strategies, contribute to the regulation of the stoichiometric relationship between elements such as carbon and silicon in the global ocean (Boyd et al., 2010; Assmy et al., 2013; Boyd, 2013; Quéguiner, 2013).

Bottom-tethered sediment traps have contributed significantly to the characterisation of the spatial and temporal variability of biochemical and microorganism fluxes in the Southern Ocean (Romero and Armand, 2010). For example, sediment trap experiments have revealed that the particle export in this region is highly seasonal and that maximum fluxes of particulate matter occur in areas under the influence of seasonal sea ice where diatoms are most abundant (e.g. Fischer et al., 2002; Pilskaln et al., 2004; Grigorov et al., 2014). Other studies have revealed the crucial role of particular diatom species in driving the biological pump in naturally iron-fertilised waters, such as Chaetoceros and Thalassiosira resting spores around the Kerguelen Plateau (Rembauville et al., 2015) or the resting stages of Eucampia antarctica in the Crozet Islands system (Salter et al., 2012). Most of these studies have been carried out in areas of relatively high primary production such as coastal systems and areas under the influence of seasonal sea ice. However, very few sediment trap experiments have been conducted in the pelagic province that, despite its relatively low phytoplankton abundance, is responsible for approximately $90 \%$ of the annual primary production in the Southern Ocean due to its large size (Arrigo et al., 2008).

In this work we document the seasonal and inter-annual variability of the chemical (total mass, $\mathrm{BSi}$, carbonate and particulate organic carbon - POC) and biological (diatom assemblages) composition of the material captured at two mooring sites along the $140^{\circ} \mathrm{E}$ meridian, representative of a large proportion of the Subantarctic Zone (SAZ) and Polar Frontal Zone (PFZ). The main objectives of this study are

1. to document the latitudinal and seasonal variations in the composition of the particle fluxes and diatom communities across sites; 
2. to assess the role of the seasonal variability of diatom communities on the biological pump and cycling of silica;

3. to provide annual estimates of biogenic silica, carbonate, POC and diatom-valve fluxes to the deep ocean for the SAZ and PFZ.

\section{Oceanographic and biological setting}

The Southern Ocean is divided into concentric zones surrounding Antarctica by a series of frontal systems (Fig. 1), which are characterized by large geostrophic surface velocities (Orsi et al., 1995) and are linked to contours of sea surface height (SSH; Sokolov and Rintoul, 2002, 2009b, a). Between these fronts lie zones of weak flow that tend to have relatively uniform water mass properties (Zentara and Kamykowski, 1981; Rintoul and Bullister, 1999) and biological characteristics (Boyd, 2002; Thomalla et al., 2011). The SAZ extends from the subtropical front (STF) to the Subantarctic Front (SAF) and represents a transition zone between the subtropical gyres to the north and the ACC to the south (Rintoul and Bullister, 1999). SAZ surface waters along $\sim 140^{\circ} \mathrm{E}$ have summer sea surface temperatures (SSTs) ranging between 11 and $12^{\circ} \mathrm{C}$ (Fig. 2), whilst the mixed layer depth during winter can exceed $600 \mathrm{~m}$ (Rintoul and Trull, 2001). The SAF is characterised by a marked latitudinal surface gradient in temperature and salinity and, in the Australian sector, is split into two branches or filaments at mean latitudes of 50.5 and $52^{\circ} \mathrm{S}$ (Sokolov and Rintoul, 2002). The PFZ lies just south of the SAZ and represents the northernmost extent of the Antarctic waters. PFZ surface waters have summer SSTs typically between 5 and $6{ }^{\circ} \mathrm{C}$ in summer (Fig. 3), but the winter mixed layer is shallower (less than $200 \mathrm{~m}$ ) than at the SAZ (Rintoul and Trull, 2001).

Together the SAZ and PFZ make up the sub-Antarctic region (Fig. 1), which is the site of the formation of the subantarctic mode and Antarctic Intermediate waters (SAMW and AAIW, respectively; McCartney, 1977). Both SAMW and AAIW are subducted northward beneath the subtropical gyres ventilating their lower thermocline (Sallée et al., 2006; Downes et al., 2009) and eventually supplying with nutrients the surface waters across the oceans of the Southern Hemisphere and North Atlantic (Sarmiento et al., 2004).

In terms of biogeochemical distributions, the SAZ and PFZ can be defined as HNLC regimes but with a remarkable difference between them. While PFZ surface waters are replete with phosphate, nitrate and silicate until at least midsummer, in the SAZ silicate remains at low levels throughout the year (Rintoul and Trull, 2001; Wang et al., 2001). Dissolved iron concentrations in the mixed layer along the $140^{\circ} \mathrm{E}$ longitude transect are low and exhibit a decreasing trend with increasing latitude, with 0.27 in the SAZ and $0.22 \pm 0.02 \mathrm{nmol} \mathrm{L}^{-1}$ in the PFZ (Lannuzel et al., 2011). Primary production is thought to be co-limited by iron supply

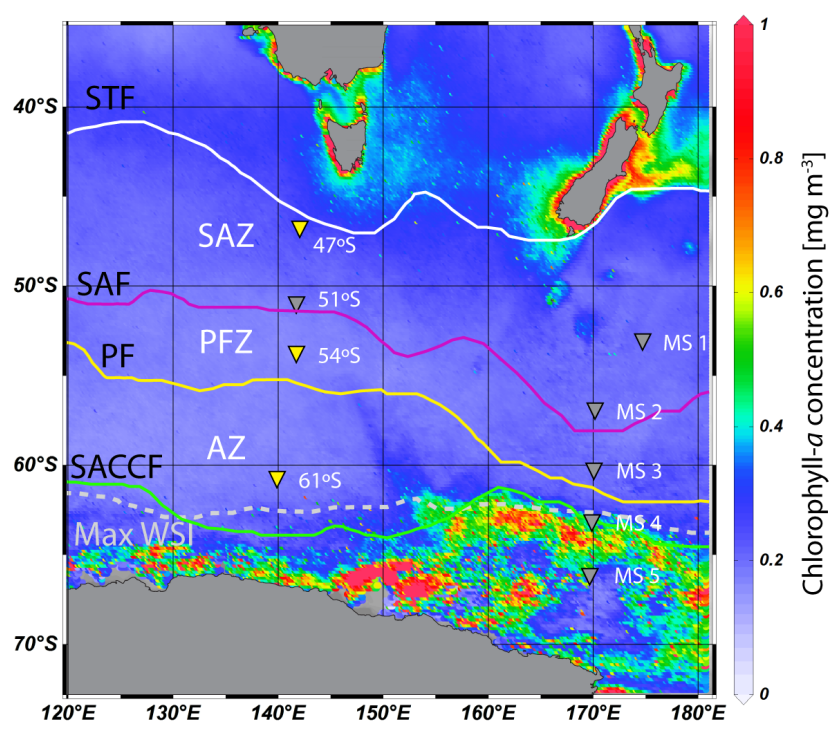

Figure 1. Southern Ocean chlorophyll $a$ composite map (September 1997 to September 2007) from Sea-viewing Wide Field-of-View Sensor (SeaWiFS) with the location of the sediment trap moorings of the SAZ (47, 51, 54 and $61^{\circ} \mathrm{S}$ ) and AESOPS (MS-1, MS-2, MS-3, MS-4 and MS-5) experiments. Abbreviations: STF - subtropical front, SAZ - Subantarctic Zone, SAF - Subantarctic Front, PFZ - Polar Frontal Zone, PF - polar front, AZ - Antarctic zone, SACC - Southern extent of the Antarctic Circumpolar Current, Max WSI - maximum winter sea ice extent. Oceanic fronts from Orsi et al. (1995). Sea ice extent from Fetterer et al. (2002, updated 2009).

and light in the PFZ, and by iron supply and low silicic acid concentration in the case of the SAZ (Boyd et al., 1999; Boyd et al., 2001; Lannuzel et al., 2011).

As a consequence of these different physical and biochemical properties, the SAZ and PFZ exhibit two distinct phytoplankton communities. SAZ surface waters are dominated by coccolithophores, other flagellates and cyanobacteria with lower abundances of diatoms. PFZ waters are also rich in coccolithophores and flagellates, but contain few cyanobacteria, whereas diatoms are more abundant and of larger size (Popp et al., 1999; Kopczynska et al., 2001; de Salas et al., 2011). Finally, it is worthy to note a feature present in the PFZ but not in the SAZ; a subsurface chlorophyll maximum (SCM) dominated by large diatom species (Kopczynska et al., 2001) has been consistently reported during summer in the PFZ within or beneath the seasonal pycnocline. The formation and maintenance of this SCM is most likely due to the settling of phytoplankton cells as a response to iron and silicate co-limitation in the mixed layer during summer (Popp et al., 1999; Parslow et al., 2001). 

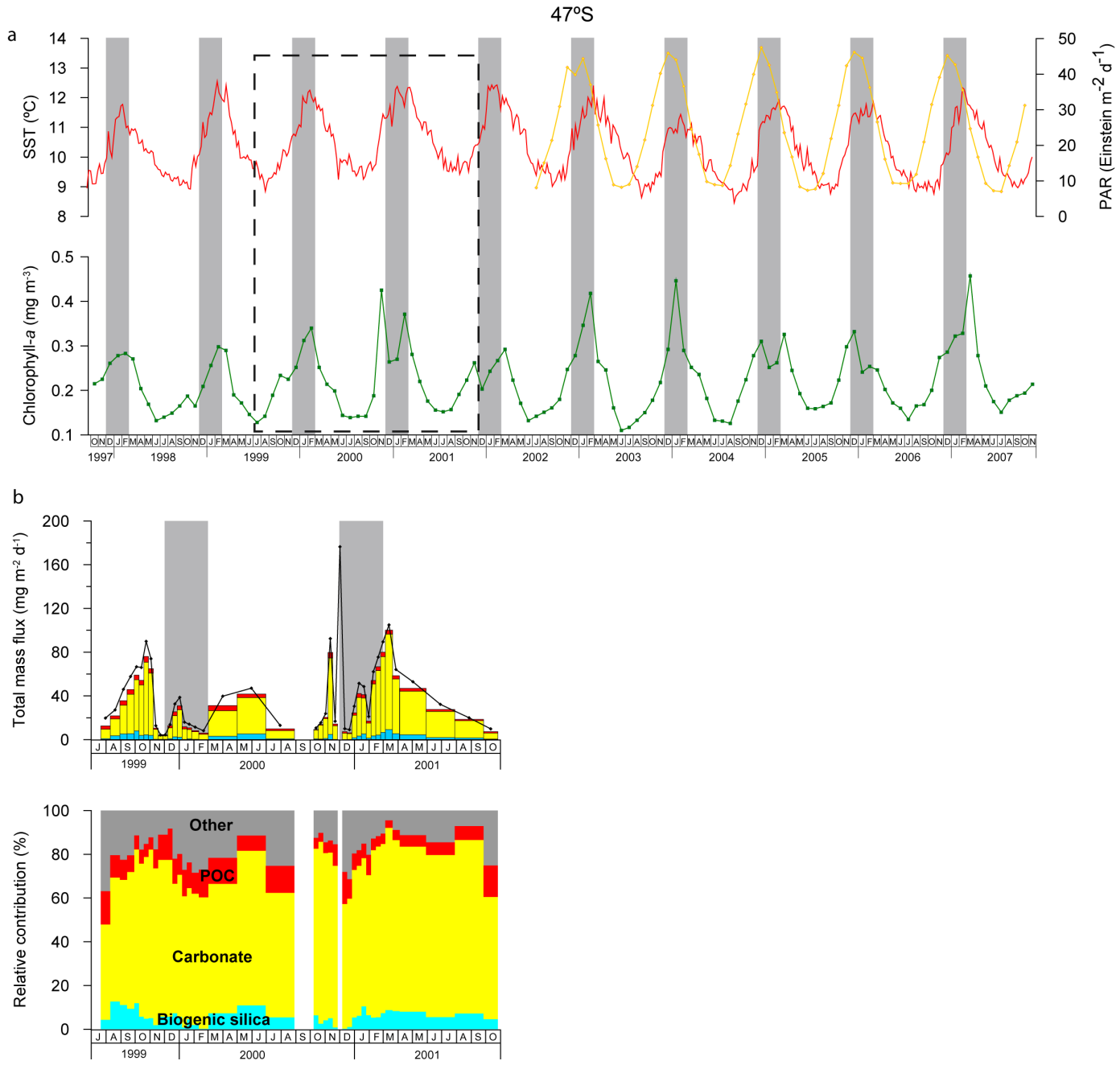

Figure 2. (a) Available mean sea surface temperature (SST), photosynthetically available radiation (PAR) and chlorophyll $a$ concentration for the $47^{\circ} \mathrm{S}$ site. The dashed intervals represent the studied periods. (b) Temporal variability of the total and major component fluxes, and their relative contributions to the total mass flux for the $<1 \mathrm{~mm}$ fraction at $1000 \mathrm{~m}$ water depth at the $47^{\circ} \mathrm{S}$ site for the period July $1999-$ October 2001. Biogenic silica, carbonate and particulate organic carbon (POC) were directly measured. "Other" indicates un-characterized mass contributions (organic components other than carbon and small amounts of lithogenic material; Trull et al., 2001). Grey horizontal bars highlight the summer period (December to February) of each year.

\section{Material and methods}

\subsection{Field experiment}

A series of deep-moored sediment trap deployments was instigated in 1997 by the Australian SAZ program (Trull et al., 2001b) and now continues as a component of the Australian Integrated Marine Observing System Southern Ocean Time Series (Trull et al., 2010; Shadwick et al., 2015). Two sites representative of a large proportion of the SAZ and PFZ were occupied quasi-continuously for the decade 19972007. Both sites were located along the $140^{\circ} \mathrm{E}$ longitude: station $47^{\circ} \mathrm{S}$ was set on the abyssal plain of the central SAZ, whereas station $54^{\circ} \mathrm{S}$ was placed on a bathymetric high of the Southeast Indian Ridge in the PFZ (Fig. 1, Table 1). Ad- ditionally, two other sites were instrumented over a 1-year period, beneath the SAF (site $51^{\circ} \mathrm{S}, 1997-1998$ ) and within the southern Antarctic Zone (AZ) (site $61^{\circ} \mathrm{S}, 2001-2002$ ). Here, we present data from the $47^{\circ} \mathrm{S} 1000 \mathrm{~m}$ trap between 1999 and 2001 (2-year record) and from the $54^{\circ} \mathrm{S} 800 \mathrm{~m}$ trap between the following years: 1997-1998, 1999-2000, 20022004 and 2005-2007 (6-year record). Biogenic particle flux data of sites 47,51 and $54^{\circ} \mathrm{S}$ for the first year deployment (1997-1998) and of site $61^{\circ} \mathrm{S}$ for the year 2001-2002 have already been published in Trull et al. (2001a) and RigualHernández et al. (2015), respectively.

All traps were MacLane Parflux sediment traps: conical in shape with a $0.5 \mathrm{~m}^{2}$ opening area and equipped with a carrousel of 13 or 21 sampling cups. Cup rotation intervals 

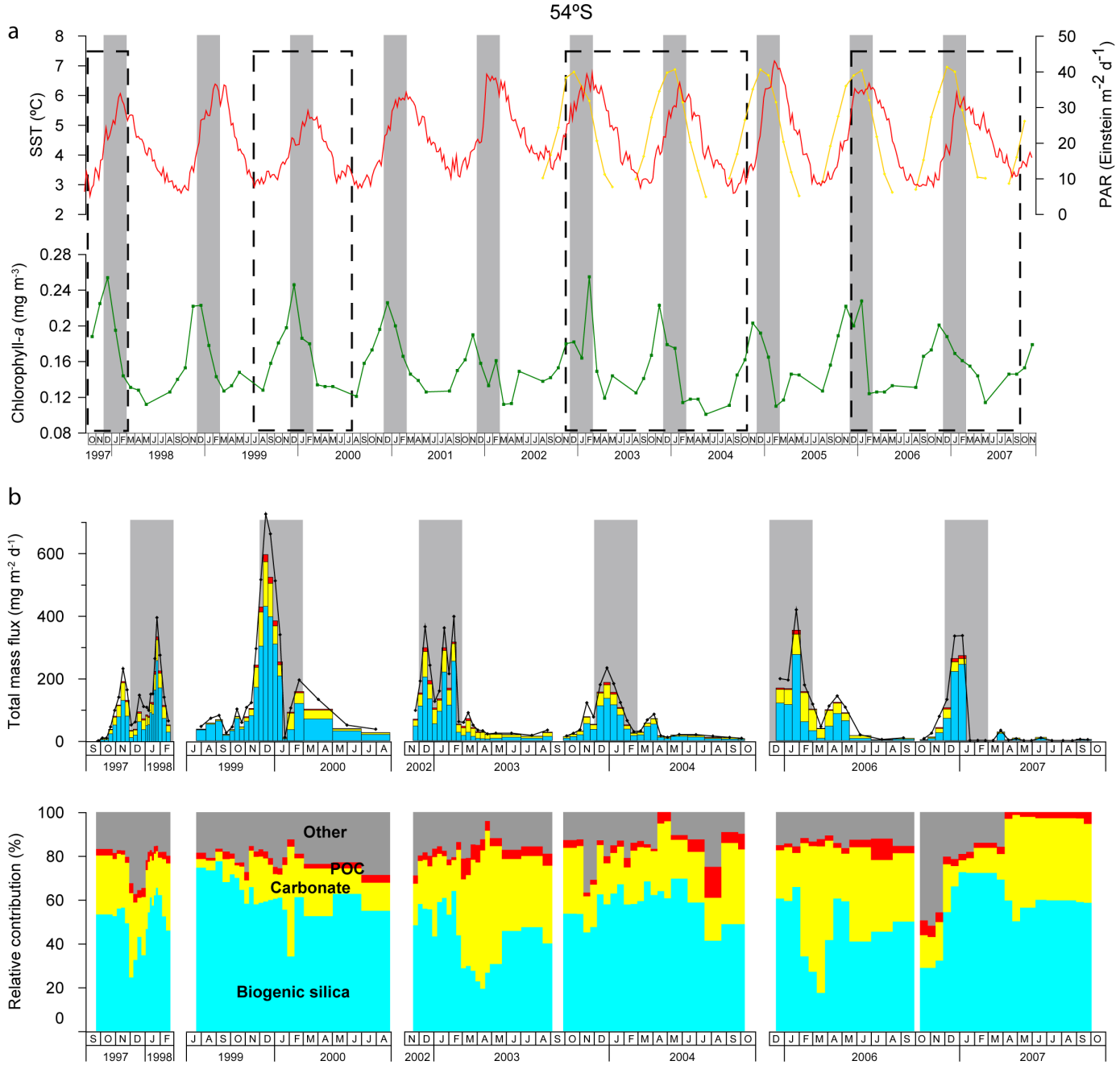

Figure 3. (a) Available mean sea surface temperature (SST), photosynthetically available radiation (PAR) and chlorophyll $a$ concentration for the $54^{\circ} \mathrm{S}$ site. The dashed intervals represent the studied periods. (b) Temporal variability of the total and major component fluxes, and their relative contributions to the total mass flux for the $<1 \mathrm{~mm}$ fraction at $800 \mathrm{~m}$ water depth at the $54^{\circ} \mathrm{S}$ site for the periods July $1999-$ August 2000, November 2002-October 2004 and December 2005-October 2007. Biogenic silica, carbonate and particulate organic carbon (POC) were directly measured. "Other" indicates un-characterised mass contributions (organic components other than carbon and small amounts of lithogenic material; Trull et al., 2001). Grey horizontal bars highlight the summer period (December to February) of each year.

Table 1. Deployment summary of sediment traps at stations 47,54 and $61^{\circ} \mathrm{S}$.

\begin{tabular}{llrrrr}
\hline $\begin{array}{l}\text { Site and trap } \\
\text { designations }\end{array}$ & $\begin{array}{l}\text { Hydrographic } \\
\text { zone }\end{array}$ & $\begin{array}{r}\text { Latitude } \\
{ }^{\circ} \mathrm{S}\end{array}$ & $\begin{array}{r}\text { Longitude } \\
{ }^{\circ} \mathrm{E}\end{array}$ & $\begin{array}{r}\text { Water column } \\
\text { depth }(\mathrm{m})\end{array}$ & $\begin{array}{r}\text { Trap depth } \\
(\mathrm{m})\end{array}$ \\
\hline $47^{\circ} \mathrm{S} \_1000$ & SAZ & $46^{\circ} 46^{\prime} \mathrm{S}$ & $142^{\circ} 4^{\prime} \mathrm{E}$ & 4540 & 1060 \\
$54^{\circ} \mathrm{S} \_800$ & $\mathrm{PFZ}$ & $53^{\circ} 45^{\prime} \mathrm{S}$ & $141^{\circ} 45^{\prime} \mathrm{E}$ & 2280 & 830 \\
$61^{\circ} \mathrm{S} 2000$ & $\mathrm{AZ}$ & $60^{\circ} 44^{\prime} \mathrm{S}$ & $139^{\circ} 54^{\prime} \mathrm{E}$ & 4393 & 2000 \\
\hline
\end{tabular}

were established based on anticipated mass fluxes. The shortest intervals corresponded with the austral summer and autumn ranging typically between 4.25 and 10 days, whereas the longest intervals were 60 days, corresponding with winter (Table 2). Each trap was paired with an Aanderaa current metre and temperature sensor. The $250 \mathrm{~mL}$ collection cups were filled with a buffered solution of sodium tetraborate $\left(1 \mathrm{~g} \mathrm{~L}^{-1}\right)$, sodium chloride $\left(5 \mathrm{~g} \mathrm{~L}^{-1}\right)$ and mercury chloride $\left(3 \mathrm{~g} \mathrm{~L}^{-1}\right)$ in unfiltered deep seawater from the region (collected at $1200 \mathrm{~m}$ depth, $49^{\circ} 17^{\prime} \mathrm{S}, 153^{\circ} 58^{\prime} \mathrm{E}$ ). Full details of the mooring designs can be found in Bray et al. (2000) and Trull et al. (2001a). 
Table 2. Individual cup fluxes for the $<1 \mathrm{~mm}$ fraction.

\begin{tabular}{|c|c|c|c|c|c|c|c|c|c|c|c|}
\hline Deployment & Cup & $\begin{array}{r}\text { Sampling period } \\
\text { mid-point }\end{array}$ & $\begin{array}{r}\text { Length } \\
\text { days }\end{array}$ & $\begin{array}{r}\text { Diatoms } \\
10^{6} \text { valves } \mathrm{m}^{-2} \mathrm{~d}^{-1}\end{array}$ & $\begin{array}{r}\text { Total mass } \\
\mathrm{mg} \mathrm{m}^{-2} \mathrm{~d}^{-1}\end{array}$ & $\begin{array}{r}\mathrm{BSiO}_{2} \\
\mathrm{mg} \mathrm{m}{ }^{-2} \mathrm{~d}^{-1}\end{array}$ & $\%$ & $\begin{array}{r}\mathrm{CaCO}_{3} \\
\mathrm{mg} \mathrm{m}^{-2} \mathrm{~d}^{-1}\end{array}$ & $\%$ & $\begin{array}{r}\text { POC } \\
\mathrm{mg} \mathrm{m}^{-2} \mathrm{~d}^{-1}\end{array}$ & $\%$ \\
\hline \multirow{21}{*}{$\begin{array}{l}47^{\circ} \mathrm{S} 1000 \mathrm{~m}, \\
1999-2000\end{array}$} & 1 & $31 / 07 / 1999$ & 20.0 & 0.002 & 19.6 & 0.8 & 4 & 8.6 & 44 & 3.0 & 15 \\
\hline & 2 & 20/08/1999 & 20.0 & 0.113 & 27.1 & 3.4 & 13 & 15.3 & 57 & 2.8 & 10 \\
\hline & 3 & 06/09/1999 & 15.0 & 0.195 & 45.9 & 5.1 & 11 & 26.2 & 57 & 4.2 & 9 \\
\hline & 4 & 21/09/1999 & 15.0 & 0.147 & 57.5 & 5.4 & 9 & 36.0 & 63 & 4.4 & 8 \\
\hline & 5 & 04/10/1999 & 10.0 & 0.213 & 66.5 & 7.9 & 12 & 46.8 & 70 & 4.2 & 6 \\
\hline & 6 & 14/10/1999 & 10.0 & 0.364 & 65.9 & 3.8 & 6 & 46.1 & 70 & 4.2 & 6 \\
\hline & 7 & $24 / 10 / 1999$ & 10.0 & 0.137 & 89.8 & 4.3 & 5 & 66.4 & 74 & 5.3 & 6 \\
\hline & 8 & 03/11/1999 & 10.0 & 0.080 & 73.9 & 3.8 & 5 & 56.9 & 77 & 4.1 & 6 \\
\hline & 9 & 13/11/1999 & 10.0 & & 12.7 & 0.2 & 2 & $9.1^{*}$ & $72^{*}$ & $1.1^{*}$ & $9^{*}$ \\
\hline & 10 & 23/11/1999 & 10.0 & & 4.2 & $0.2^{*}$ & $6^{*}$ & $3^{*}$ & $72 *$ & $0.5^{*}$ & $12^{*}$ \\
\hline & 11 & 03/12/1999 & 10.0 & & 4.3 & $0.2^{*}$ & $6^{*}$ & $3.1^{*}$ & $72^{*}$ & $0.5^{*}$ & $12 *$ \\
\hline & 12 & $13 / 12 / 1999$ & 10.0 & & 13.8 & $0.8^{*}$ & $6^{*}$ & $9.9^{*}$ & $72^{*}$ & $2.0^{*}$ & $14^{*}$ \\
\hline & 13 & 23/12/1999 & 10.0 & 0.049 & 32.6 & 2.4 & 7 & 19.3 & 59 & 3.7 & 11 \\
\hline & 14 & $02 / 01 / 2000$ & 10.0 & 0.001 & 38.5 & 2.2 & 6 & 25.0 & 65 & 3.6 & 9 \\
\hline & 15 & $12 / 01 / 2000$ & 10.0 & & 15.9 & 0.1 & 1 & $9.5^{*}$ & $60^{*}$ & $1.9^{*}$ & $12^{*}$ \\
\hline & 16 & $22 / 01 / 2000$ & 10.0 & & 14.0 & 0.6 & 5 & $8.4^{*}$ & $60^{*}$ & $1.6^{*}$ & $12 *$ \\
\hline & 17 & 03/02/2000 & 15.0 & 0.002 & 11.4 & 0.2 & 2 & $6.8^{*}$ & $60^{*}$ & $1.1^{*}$ & $10^{*}$ \\
\hline & 18 & $21 / 02 / 2000$ & 20.0 & & 8.0 & & & $4.8^{*}$ & $60^{*}$ & $1.0^{*}$ & $13^{*}$ \\
\hline & 19 & $01 / 04 / 2000$ & 60.0 & 0.110 & 39.6 & 2.9 & 7 & 23.4 & 59 & 4.7 & 12 \\
\hline & 20 & $31 / 05 / 2000$ & 60.0 & 0.125 & 47.0 & 5.1 & 11 & 33.2 & 71 & 3.3 & 7 \\
\hline & 21 & $30 / 07 / 2000$ & 60.0 & 0.002 & 13.0 & 0.7 & 5 & 7.4 & 57 & 1.6 & 12 \\
\hline \multirow{21}{*}{$\begin{array}{l}47^{\circ} \mathrm{S} 1000 \mathrm{~m}, \\
2000-2001\end{array}$} & 1 & $13 / 10 / 2000$ & 10.0 & & 10.5 & 0.7 & 6 & 8.0 & 76 & 0.5 & 5 \\
\hline & 2 & $23 / 10 / 2000$ & 10.0 & & 15.3 & 0.4 & 3 & 12.7 & 83 & 0.6 & 4 \\
\hline & 3 & $02 / 11 / 2000$ & 10.0 & 0.164 & 23.7 & 1.0 & 4 & 18.2 & 76 & 1.2 & 5 \\
\hline & 4 & $12 / 11 / 2000$ & 10.0 & 1.559 & 92.3 & 4.6 & 5 & 69.9 & 76 & 5.1 & 6 \\
\hline & 5 & $22 / 11 / 2000$ & 10.0 & 0.037 & 16.7 & 0.1 & 1 & $12.3^{*}$ & $74^{*}$ & $1.6^{*}$ & $10^{*}$ \\
\hline & 6 & $02 / 12 / 2000$ & 10.0 & 0.001 & 176.3 & & & & & & \\
\hline & 7 & $12 / 12 / 2000$ & 10.0 & & 9.9 & & & 5.7 & 57 & 1.5 & 15 \\
\hline & 8 & $22 / 12 / 2000$ & 10.0 & & 8.9 & 0.1 & 1 & 5.2 & 59 & 0.8 & 9 \\
\hline & 9 & 01/01/2001 & 10.0 & 0.053 & 30.4 & 1.6 & 5 & 20.5 & 67 & 2.3 & 8 \\
\hline & 10 & $11 / 01 / 2001$ & 10.0 & 0.345 & 51.3 & 3.2 & 6 & 35.2 & 69 & 3.6 & 7 \\
\hline & 11 & $21 / 01 / 2001$ & 10.0 & 0.200 & 48.4 & 5.1 & 10 & 32.8 & 68 & 3.2 & 7 \\
\hline & 12 & $31 / 01 / 2001$ & 10.0 & 0.089 & 21.1 & 1.4 & 6 & 13.5 & 64 & 2.0 & 9 \\
\hline & 13 & $10 / 02 / 2001$ & 10.0 & 0.077 & 62.0 & 3.3 & 5 & 47.5 & 77 & 3.3 & 5 \\
\hline & 14 & $20 / 02 / 2001$ & 10.0 & 0.435 & 75.4 & 4.1 & 5 & 58.8 & 78 & 3.6 & 5 \\
\hline & 15 & $02 / 03 / 2001$ & 10.0 & 0.758 & 89.4 & 6.5 & 7 & 69.1 & 77 & 4.2 & 5 \\
\hline & 16 & $14 / 03 / 2001$ & 15.0 & 0.398 & 104.8 & 9.1 & 9 & 87.3 & 83 & 3.5 & 3 \\
\hline & 17 & $29 / 03 / 2001$ & 15.0 & & $64.0^{*}$ & $5.3^{*}$ & $8^{*}$ & $50.0^{*}$ & $78^{*}$ & $2.9^{*}$ & $5^{*}$ \\
\hline & 18 & 03/05/2001 & 55.0 & 0.231 & 52.9 & 4.2 & 8 & 39.9 & 75 & 2.7 & 5 \\
\hline & 19 & $30 / 06 / 2001$ & 60.0 & 0.293 & 32.2 & 1.8 & 6 & 23.9 & 74 & 1.9 & 6 \\
\hline & 20 & $29 / 08 / 2001$ & 60.0 & 0.126 & 19.8 & 1.4 & 7 & 15.7 & 79 & 1.3 & 6 \\
\hline & 21 & $13 / 10 / 2001$ & 30.0 & 0.038 & 9.7 & 0.4 & 5 & 5.4 & 56 & 1.4 & 14 \\
\hline
\end{tabular}

\subsection{Quality check of downward particle fluxes}

Current speeds largely influence the efficiency with which sediment traps collect the particles sinking in the water column (Baker et al., 1988; Yu et al., 2001). The threshold of current velocity above which sinking particles are no longer quantitatively sampled is not well known, but has been suggested to be around $12 \mathrm{~cm} \mathrm{~s}^{-1}$ (Baker et al., 1988). Average current speeds for the whole sampling interval at the trap levels were lower than $11 \mathrm{~cm} \mathrm{~s}^{-1}$ for both sites and showed little seasonal variability (Bray, unpublished results, available online at imos.org.au). Therefore, these mild conditions seem to be sub-critical for any strong concerns over collection efficiencies. Additionally, radioisotope analyses of material from the first year deployment by Trull et al. (2001) provide some extra insights to assess the collection efficiency of the traps. The ${ }^{230}$ Th flux/production ratios for the 1997-1998 de- ployment were $0.6 \pm 0.1$ and $0.7 \pm 0.1$ for the 47 and $54^{\circ} \mathrm{S}$ traps, respectively. These values suggest that some degree of under trapping is likely to have occurred at both sites. However, as these values are almost identical for both traps, it can be assumed that the trapping efficiency did not account for the observed latitudinal variations in the magnitude of the particle export between sites. Taking into consideration all the above and the fact that the assessment of trapping efficiency from ${ }^{230} \mathrm{Th}$ alone is fraught with uncertainties (Trull et al., 2001a; Buesseler et al., 2007), trap fluxes were not corrected for possible under trapping in the present study.

\subsection{Determination of major constituents of the flux}

A detailed description of the methodology used for the determination of the flux intensity and composition of settling particles for the first mooring deployments in 1997-1998 can be found in Bray et al. (2000) and Trull et al. (2001a). After 
Table 2. Continued.

\begin{tabular}{|c|c|c|c|c|c|c|c|c|c|c|c|}
\hline Deployment & Cup & $\begin{array}{r}\text { Sampling period } \\
\text { mid-point }\end{array}$ & $\begin{array}{r}\text { Length } \\
\text { days }\end{array}$ & $\begin{array}{r}\text { Diatoms } \\
10^{6} \text { valves } \mathrm{m}^{-2} \mathrm{~d}^{-1}\end{array}$ & $\begin{array}{r}\text { Total mass } \\
\mathrm{mg} \mathrm{m}^{-2} \mathrm{~d}^{-1}\end{array}$ & $\begin{array}{r}\mathrm{BSiO}_{2} \\
\mathrm{mg} \mathrm{m}^{-2} \mathrm{~d}^{-1}\end{array}$ & $\%$ & $\begin{array}{r}\mathrm{CaCO}_{3} \\
\mathrm{mg} \mathrm{m}^{-2} \mathrm{~d}^{-1}\end{array}$ & $\%$ & $\begin{array}{r}\text { POC } \\
\mathrm{mg} \mathrm{m}^{-2} \mathrm{~d}^{-1}\end{array}$ & $\%$ \\
\hline \multirow{21}{*}{$\begin{array}{l}54^{\circ} \mathrm{S} 800 \mathrm{~m}, \\
1997-1998\end{array}$} & 1 & $26 / 09 / 1997$ & 8.5 & 0.275 & 2.7 & $1.4^{*}$ & $53 *$ & 0.7 & 27 & $0.1^{*}$ & $3^{*}$ \\
\hline & 2 & 04/10/1997 & 8.5 & & 11.5 & $6.1^{*}$ & $53^{*}$ & 3.1 & 27 & $0.3^{*}$ & $3^{*}$ \\
\hline & 3 & 13/10/1997 & 8.5 & & 11.5 & $6.1^{*}$ & $53^{*}$ & 3.1 & 27 & $0.3^{*}$ & $3^{*}$ \\
\hline & 4 & 21/10/1997 & 8.5 & 4.561 & 47.0 & 25.1 & 53 & 12.6 & 27 & 1.4 & 3 \\
\hline & 5 & $30 / 10 / 1997$ & 8.5 & 13.121 & 100.0 & 52.5 & 53 & 26.0 & 26 & 2.7 & 3 \\
\hline & 6 & 07/11/1997 & 8.5 & 20.564 & 141.7 & 79.3 & 56 & 35.5 & 25 & 2.3 & 2 \\
\hline & 7 & 16/11/1997 & 8.5 & 26.211 & 233.5 & 131.7 & 56 & 56.4 & 24 & 4.3 & 2 \\
\hline & 8 & $24 / 11 / 1997$ & 8.5 & 11.542 & 165.8 & 81.7 & 49 & 45.8 & 28 & 4.4 & 3 \\
\hline & 9 & 03/12/1997 & 8.5 & 4.914 & 53.3 & 13.1 & 25 & 20.5 & 38 & 2.4 & 4 \\
\hline & 10 & $11 / 12 / 1997$ & 8.5 & & 63.2 & 20.5 & 33 & 16.6 & 26 & 2.5 & 4 \\
\hline & 11 & 20/12/1997 & 8.5 & 11.711 & 148.2 & 63.8 & 43 & 26.5 & 18 & 5.0 & 3 \\
\hline & 12 & 28/12/1997 & 8.5 & 20.881 & 111.9 & 38.8 & 35 & 29.7 & 27 & 4.6 & 4 \\
\hline & 13 & 04/01/1998 & 4.3 & 34.729 & 109.7 & 51.2 & 47 & 29.5 & 27 & 4.9 & 5 \\
\hline & 14 & 08/01/1998 & 4.3 & & 99.9 & 54.2 & 54 & 23.0 & 23 & 4.5 & 5 \\
\hline & 15 & $12 / 01 / 1998$ & 4.3 & & 151.8 & 92.7 & 61 & 28.7 & 19 & 4.0 & 3 \\
\hline & 16 & $16 / 01 / 1998$ & 4.3 & & 153.0 & 87.8 & 57 & 31.5 & 21 & 5.8 & 4 \\
\hline & 17 & 21/01/1998 & 4.3 & 70.808 & 265.5 & 164.7 & 62 & 50.6 & 19 & 8.8 & 3 \\
\hline & 18 & $25 / 01 / 1998$ & 4.3 & 54.059 & 396.0 & 259.2 & 65 & 66.0 & 17 & 9.9 & 2 \\
\hline & 19 & $31 / 01 / 1998$ & 8.5 & 41.101 & 276.2 & 171.7 & 62 & 47.2 & 17 & 7.0 & 3 \\
\hline & 20 & 09/02/1998 & 8.5 & 28.947 & 141.7 & 74.3 & 52 & 37.0 & 26 & 4.6 & 3 \\
\hline & 21 & $17 / 02 / 1998$ & 8.5 & & 66.4 & 30.5 & 46 & 20.4 & 31 & 2.3 & 3 \\
\hline \multirow{21}{*}{$\begin{array}{l}54^{\circ} \mathrm{S} 800 \mathrm{~m}, \\
1999-2000\end{array}$} & 1 & $31 / 07 / 1999$ & 20.0 & 9.681 & 45.9 & 34.3 & 75 & 1.8 & 4 & 1.3 & 3 \\
\hline & 2 & 20/08/1999 & 20.0 & 10.944 & 71.8 & 52.8 & 74 & 3.2 & 4 & 0.9 & 1 \\
\hline & 3 & 06/09/1999 & 15.0 & 7.948 & 81.4 & 63.2 & 78 & 3.6 & 4 & 1.1 & 1 \\
\hline & 4 & 21/09/1999 & 15.0 & 4.867 & 25.1 & 17.1 & 68 & 2.6 & 10 & 0.9 & 3 \\
\hline & 5 & 04/10/1999 & 10.0 & 5.622 & 44.5 & 31.9 & 72 & 3.2 & 7 & 1.0 & 2 \\
\hline & 6 & $14 / 10 / 1999$ & 10.0 & 9.942 & 101.1 & 70.8 & 70 & 5.8 & 6 & 1.1 & 1 \\
\hline & 7 & 24/10/1999 & 10.0 & 8.689 & 58.2 & 37.6 & 65 & 6.2 & 11 & 1.1 & 2 \\
\hline & 8 & 03/11/1999 & 10.0 & 5.857 & 106.3 & 62.0 & 58 & 11.3 & 11 & 3.9 & 4 \\
\hline & 9 & 13/11/1999 & 10.0 & 6.081 & 121.9 & 80.3 & 66 & 20.2 & 17 & 2.6 & 2 \\
\hline & 10 & 23/11/1999 & 10.0 & 28.312 & 294.4 & 170.7 & 58 & 63.8 & 22 & 7.1 & 2 \\
\hline & 11 & 03/12/1999 & 10.0 & 51.610 & 514.8 & 302.5 & 59 & 108.5 & 21 & 16.7 & 3 \\
\hline & 12 & $13 / 12 / 1999$ & 10.0 & 10.590 & 724.4 & 429.3 & 59 & 142.5 & 20 & 23.0 & 3 \\
\hline & 13 & 23/12/1999 & 10.0 & 15.287 & 660.6 & 396.3 & 60 & 106.2 & 16 & 20.0 & 3 \\
\hline & 14 & $02 / 01 / 2000$ & 10.0 & 19.142 & 511.0 & 309.1 & 61 & 57.8 & 11 & 16.4 & 3 \\
\hline & 15 & $12 / 01 / 2000$ & 10.0 & 17.274 & 338.7 & 207.0 & 61 & 35.5 & 10 & 9.5 & 3 \\
\hline & 16 & $22 / 01 / 2000$ & 10.0 & & 11.3 & 6.3 & 56 & 2.3 & 20 & 0.4 & 3 \\
\hline & 17 & $03 / 02 / 2000$ & 15.0 & 3.892 & 104.4 & 35.7 & 34 & 52.3 & 50 & 3.4 & 3 \\
\hline & 18 & $21 / 02 / 2000$ & 20.0 & 11.224 & 193.9 & 118.8 & 61 & 34.4 & 18 & 4.1 & 2 \\
\hline & 19 & $01 / 04 / 2000$ & 60.0 & 4.764 & 132.0 & 69.4 & 53 & 28.7 & 22 & 2.8 & 2 \\
\hline & 20 & $31 / 05 / 2000$ & 60.0 & 3.390 & 50.1 & 31.5 & 63 & 5.8 & 12 & 1.4 & 3 \\
\hline & 21 & $30 / 07 / 2000$ & 60.0 & 1.117 & 36.9 & 20.3 & 55 & 4.7 & 13 & 1.3 & 3 \\
\hline
\end{tabular}

recovery, sediment trap cups were allowed to settle before supernatant was drawn off with a syringe for salinity, nutrients and $\mathrm{pH}$ measurements. The remaining sample slurries were sieved through a $1 \mathrm{~mm}$ sieve and then split into 10 fractions using a rotary splitter (McLane, Inc.). Three of these splits were filtered onto Nucleopore filters ( 0.45 pore size), removed from the filter as a wet cake of material, oven-dried at $60^{\circ} \mathrm{C}$ and ground in a mortar. This material was used to determine the dry mass flux and the major components of the flux (particulate inorganic carbon (PIC), POC and biogenic silica). PIC was determined by closed system acidification with phosphoric acid and coulometry. Particulate total carbon (PC) was determined by unacidified combustion using a carbon-hydrogen-nitrogen $(\mathrm{CHN})$ elemental analyzer. POC was calculated from PC by substraction of PIC. Total silicon and aluminium contents were estimated by $\mathrm{HF}-\mathrm{HNO}_{3}$ microwave digestion and inductively coupled plasma emis- sions spectrometry following the methodology described by Bray et al. (2000). Biogenic silica was determined from total silica by subtracting lithogenic silica estimated by assuming a lithogenic $\mathrm{Al}: \mathrm{Si}$ mass ratio of 3.42 (Taylor, 1964). These methods for PIC and POC/particulate organic nitrogen (PON) were used for all subsequent years, with very slight modifications: (i) the wet cake method was replaced by drying prior to removing the material from the filter, (ii) in some years sieving and filtering was done at sea and the samples were frozen on the filters until dried upon returning to land. The silica methods varied more strongly over time: (i) for deployments beginning in 1998, 1999 and 2000, the use of HF in the digestion was replaced by high temperature combustion with lithium borate in a graphite crucible and $\mathrm{HNO}_{3}$ digestion to determine total silicon and aluminium; (ii) biogenic silica for these years (and retroactively for 1997) was calculated using the updated estimate for the lithogenic 
Table 2. Continued.

\begin{tabular}{|c|c|c|c|c|c|c|c|c|c|c|c|}
\hline Deployment & Cup & $\begin{array}{r}\text { Sampling period } \\
\text { mid-point }\end{array}$ & $\begin{array}{r}\text { Length } \\
\text { days }\end{array}$ & $\begin{array}{r}\text { Diatoms } \\
10^{6} \text { valves } \mathrm{m}^{-2} \mathrm{~d}^{-1}\end{array}$ & $\begin{array}{r}\text { Total mass } \\
\mathrm{mg} \mathrm{m}^{-2} \mathrm{~d}^{-1}\end{array}$ & $\begin{array}{r}\mathrm{BSiO}_{2} \\
\mathrm{mg} \mathrm{m}^{-2} \mathrm{~d}^{-1}\end{array}$ & $\%$ & $\begin{array}{r}\mathrm{CaCO}_{3} \\
\mathrm{mg} \mathrm{m}^{-2} \mathrm{~d}^{-1}\end{array}$ & $\%$ & $\begin{array}{c}\mathrm{POC} \\
\mathrm{mg} \mathrm{m}^{-2} \mathrm{~d}^{-1}\end{array}$ & $\%$ \\
\hline \multirow{21}{*}{$\begin{array}{l}54^{\circ} \mathrm{S} 800 \mathrm{~m}, \\
2002-2003\end{array}$} & 1 & $23 / 11 / 2002$ & 10.0 & 5.789 & 96.7 & 46.8 & 48 & 18.3 & 19 & 3.6 & 4 \\
\hline & 2 & $03 / 12 / 2002$ & 10.0 & 27.759 & 190.6 & 110.6 & 58 & 37.5 & 20 & 4.6 & 2 \\
\hline & 3 & $13 / 12 / 2002$ & 10.0 & 65.376 & 363.9 & 203.6 & 56 & 81.0 & 22 & 12.3 & 3 \\
\hline & 4 & $23 / 12 / 2002$ & 10.0 & 36.000 & 240.7 & 134.0 & 56 & 47.2 & 20 & 11.4 & 5 \\
\hline & 5 & $02 / 01 / 2003$ & 10.0 & 6.766 & 125.6 & 54.4 & 43 & 45.4 & 36 & 4.8 & 4 \\
\hline & 6 & $12 / 01 / 2003$ & 10.0 & 18.438 & 158.9 & 93.7 & 59 & 35.0 & 22 & 5.4 & 3 \\
\hline & 7 & $22 / 01 / 2003$ & 10.0 & 28.832 & 360.2 & 219.1 & 61 & 68.9 & 19 & 8.6 & 2 \\
\hline & 8 & $01 / 02 / 2003$ & 10.0 & 45.008 & 213.8 & 113.7 & 53 & 48.3 & 23 & 5.5 & 3 \\
\hline & 9 & $11 / 02 / 2003$ & 10.0 & 28.106 & 396.5 & 253.8 & 64 & 56.0 & 14 & 5.1 & 1 \\
\hline & 10 & $21 / 02 / 2003$ & 10.0 & 16.957 & 60.8 & 26.6 & 44 & 23.7 & 39 & 2.2 & 4 \\
\hline & 11 & $03 / 03 / 2003$ & 10.0 & 1.902 & 58.5 & 16.8 & 29 & 23.8 & 41 & 5.5 & 9 \\
\hline & 12 & $13 / 03 / 2003$ & 10.0 & 1.462 & 89.3 & 26.6 & 30 & 37.0 & 41 & 7.0 & 8 \\
\hline & 13 & $23 / 03 / 2003$ & 10.0 & 2.326 & 49.5 & 13.6 & 28 & 25.1 & 51 & 3.4 & 7 \\
\hline & 14 & $02 / 04 / 2003$ & 10.0 & 0.995 & 33.5 & 7.6 & 23 & 18.2 & 54 & 2.7 & 8 \\
\hline & 15 & $12 / 04 / 2003$ & 10.0 & 1.192 & 31.9 & 6.2 & 19 & 20.1 & 63 & 1.6 & 5 \\
\hline & 16 & $22 / 04 / 2003$ & 10.0 & 0.724 & 21.6 & $5.8^{*}$ & $27^{*}$ & 14.0 & 65 & 1.0 & 4 \\
\hline & 17 & $09 / 05 / 2003$ & 25.0 & 1.996 & 23.8 & 7.3 & 31 & 12.8 & 54 & 0.9 & 4 \\
\hline & 18 & $11 / 06 / 2003$ & 40.0 & 1.625 & 23.7 & 10.8 & 46 & 7.8 & 33 & 1.0 & 4 \\
\hline & 19 & $23 / 07 / 2003$ & 45.0 & 1.226 & 16.9 & 8.0 & 47 & 5.5 & 33 & 0.7 & 4 \\
\hline & 20 & $25 / 08 / 2003$ & 20.0 & 2.606 & 33.6 & 13.5 & 40 & 11.9 & 35 & 1.8 & 5 \\
\hline & 21 & $15 / 09 / 2003$ & 23.0 & & 33.6 & & & & & & \\
\hline \multirow{21}{*}{$\begin{array}{l}54^{\circ} \mathrm{S} 800 \mathrm{~m}, \\
2003-2004\end{array}$} & 1 & $04 / 10 / 2003$ & 14.0 & 0.352 & 15.1 & $8.1^{*}$ & $54^{*}$ & $4.5^{*}$ & $30^{*}$ & $0.5^{*}$ & $3^{*}$ \\
\hline & 2 & $18 / 10 / 2003$ & 14.0 & 1.143 & 23.4 & 12.6 & 54 & 7.0 & 30 & 0.8 & 3 \\
\hline & 3 & $01 / 11 / 2003$ & 14.0 & 2.808 & 34.8 & 18.6 & 54 & 10.8 & 31 & 1.1 & 3 \\
\hline & 4 & $15 / 11 / 2003$ & 14.0 & 11.519 & 121.0 & 54.6 & 45 & 19.9 & 16 & 2.0 & 2 \\
\hline & 5 & $29 / 11 / 2003$ & 14.0 & 7.748 & 75.5 & 35.9 & 48 & 14.6 & 19 & 1.6 & 2 \\
\hline & 6 & $13 / 12 / 2003$ & 14.0 & 19.892 & 178.6 & 111.6 & 62 & 40.2 & 23 & 3.6 & 2 \\
\hline & 7 & $27 / 12 / 2003$ & 14.0 & 10.320 & 232.6 & 134.8 & 58 & 43.6 & 19 & 7.2 & 3 \\
\hline & 8 & $10 / 01 / 2004$ & 14.0 & 30.998 & 182.0 & 114.5 & 63 & 33.7 & 19 & 6.2 & 3 \\
\hline & 9 & $24 / 01 / 2004$ & 14.0 & 16.786 & 121.9 & 81.7 & 67 & 21.0 & 17 & 3.3 & 3 \\
\hline & 10 & $07 / 02 / 2004$ & 14.0 & 11.142 & 63.9 & 37.0 & 58 & 10.8 & 17 & 2.7 & 4 \\
\hline & 11 & $21 / 02 / 2004$ & 14.0 & 5.982 & 28.5 & 16.6 & 58 & 7.0 & 24 & 1.0 & 4 \\
\hline & 12 & $06 / 03 / 2004$ & 14.0 & 6.189 & 31.0 & 18.4 & 59 & 7.7 & 25 & 0.9 & 3 \\
\hline & 13 & $20 / 03 / 2004$ & 14.0 & 9.824 & 66.2 & 45.3 & 68 & 10.2 & 15 & 1.0 & 2 \\
\hline & 14 & 03/04/2004 & 14.0 & 11.515 & 84.6 & 52.6 & 62 & 16.9 & 20 & 0.8 & 1 \\
\hline & 15 & $17 / 04 / 2004$ & 14.0 & 0.622 & 15.6 & $10.1^{*}$ & $65^{*}$ & 4.9 & 31 & 0.8 & 5 \\
\hline & 16 & $01 / 05 / 2004$ & 14.0 & 0.658 & 10.6 & $6.9^{*}$ & $65^{*}$ & 4.0 & 38 & 0.5 & 4 \\
\hline & 17 & $25 / 05 / 2004$ & 35.0 & 3.431 & 19.6 & 13.7 & 70 & 3.5 & 18 & 0.4 & 2 \\
\hline & 18 & $29 / 06 / 2004$ & 35.0 & 1.549 & 19.3 & 11.3 & 59 & 4.5 & 23 & 1.1 & 6 \\
\hline & 19 & 03/08/2004 & 35.0 & 1.235 & 14.5 & 6.0 & 41 & 2.8 & 20 & 2.0 & 14 \\
\hline & 20 & 07/09/2004 & 35.0 & 1.088 & 10.3 & 5.0 & 49 & 3.8 & 37 & 0.5 & 5 \\
\hline & 21 & $02 / 10 / 2004$ & 14.0 & 0.458 & 7.3 & 3.6 & 49 & 2.5 & 34 & 0.5 & 7 \\
\hline
\end{tabular}

$\mathrm{Al}$ : Si mass ratio of 3.83 (Taylor and McLennan, 1985); (iii) from 2001 onwards, total silica was not measured, instead hot alkaline digestion and colorimetry was used to estimate biogenic silica directly (following the method of Quéguiner, 2001).

\subsection{Siliceous microplankton sample preparation}

A total of 138 samples were processed for siliceous microplankton analysis. Each split was refilled with distilled water to $40 \mathrm{~mL}$, from which $10 \mathrm{~mL}$ were subsampled and buffered with a solution of sodium carbonate and sodium hydrogen carbonate $(\mathrm{pH} 8)$ and stored at $4{ }^{\circ} \mathrm{C}$ in the dark for future calcareous nannoplankton analysis. The remaining $30 \mathrm{~mL}$ were treated with potassium permanganate, hydrogen peroxide and concentrated hydrochloric acid following the methodology used by Romero et al. (1999). Three slides per sample were prepared and mounted using the stan- dard decantation method outlined by Bárcena and Abrantes (1998). This method produces random settling of the diatom valves for quantitative microscopic purposes. Siliceous microplankton analysis was carried out on permanent slides (Norland optical adhesive 61 mounting medium; refractive index: 1.56) of acid-cleaned material. Qualitative and quantitative analysis were done at $x 1000$ and $x 400$ magnifications using an Olympus BH-2 compound light optical microscope with phase-contrast illumination. In order to properly characterise the diatom assemblages, a target of 400 diatom valves was counted per sample. Owing to the strong seasonality in diatom production, some cups collected very low numbers of diatom valves. For these samples a compromise between number to be counted and time spent had to be reached but the number of valves counted was never less than 100 with the exception of cup no. 6 of year 2000-2001, and cup no. 14 of year 1999-2000 at the $47^{\circ} \mathrm{S}$ site which were not consid- 
Table 2. Continued.

\begin{tabular}{|c|c|c|c|c|c|c|c|c|c|c|c|}
\hline Deployment & Cup & $\begin{array}{r}\text { Sampling period } \\
\text { mid-point }\end{array}$ & $\begin{array}{r}\text { Length } \\
\text { days }\end{array}$ & $\begin{array}{r}\text { Diatoms } \\
10^{6} \text { valves } \mathrm{m}^{-2} \mathrm{~d}^{-1}\end{array}$ & $\begin{array}{r}\text { Total mass } \\
\mathrm{mg} \mathrm{m}^{-2} \mathrm{~d}^{-1}\end{array}$ & $\begin{array}{r}\mathrm{BSiO}_{2} \\
\mathrm{mg} \mathrm{m}^{-2} \mathrm{~d}^{-1}\end{array}$ & $\%$ & $\begin{array}{r}\mathrm{CaCO}_{3} \\
\mathrm{mg} \mathrm{m}^{-2} \mathrm{~d}^{-1}\end{array}$ & $\%$ & $\begin{array}{c}\text { POC } \\
\mathrm{mg} \mathrm{m}^{-2} \mathrm{~d}^{-1}\end{array}$ & $\%$ \\
\hline $54^{\circ} \mathrm{S} 800 \mathrm{~m}$ & 1 & $22 / 12 / 2005$ & 17.0 & 24.184 & 197.9 & 120.0 & 61 & 43.5 & 22 & 4.6 & 2 \\
\hline \multirow[t]{30}{*}{ 2005-2006 } & 2 & 08/01/2006 & 17.0 & 19.228 & 193.6 & 115.2 & 59 & 47.5 & 25 & 3.2 & 2 \\
\hline & 3 & $25 / 01 / 2006$ & 17.0 & 47.595 & 418.1 & 275.3 & 66 & 65.1 & 16 & 12.2 & 3 \\
\hline & 4 & $11 / 02 / 2006$ & 17.0 & 11.571 & 178.0 & 60.8 & 34 & 92.1 & 52 & 3.9 & 2 \\
\hline & 5 & $28 / 02 / 2006$ & 17.0 & 4.840 & 116.7 & 31.7 & 27 & 66.9 & 57 & 2.4 & 2 \\
\hline & 6 & $17 / 03 / 2006$ & 17.0 & 1.180 & 44.9 & 7.9 & 17 & 30.1 & 67 & 1.5 & 3 \\
\hline & 8 & $20 / 04 / 2006$ & 17.0 & 11.216 & 142.8 & 86.5 & 61 & 33.0 & 23 & 3.1 & 2 \\
\hline & 9 & $07 / 05 / 2006$ & 17.0 & 9.477 & 107.0 & 63.5 & 59 & 23.3 & 22 & 2.6 & 2 \\
\hline & 10 & 07/06/2006 & 45.0 & 0.904 & 18.6 & 7.6 & 41 & 8.0 & 43 & 0.6 & 3 \\
\hline & 11 & $22 / 07 / 2006$ & 45.0 & 0.072 & 3.6 & $1.6^{*}$ & $45^{*}$ & 1.2 & 33 & 0.4 & 10 \\
\hline & 12 & 05/09/2006 & 45.0 & 0.778 & 9.1 & 4.6 & 50 & 2.8 & 31 & 0.3 & 3 \\
\hline & 1 & $18 / 10 / 2006$ & 16.0 & 0.291 & 6.4 & $1.9^{*}$ & $29^{*}$ & 1.0 & 15 & 0.4 & 7 \\
\hline & 2 & $03 / 11 / 2006$ & 16.0 & 1.065 & 23.9 & 6.9 & 29 & 3.4 & 14 & 1.2 & 5 \\
\hline & 3 & $19 / 11 / 2006$ & 16.0 & 4.461 & 77.6 & 25.1 & 32 & 13.6 & 18 & 3.4 & 4 \\
\hline & 5 & $21 / 12 / 2006$ & 16.0 & 72.099 & 333.9 & 220.9 & 66 & 30.8 & 9 & 10.5 & 3 \\
\hline & 6 & $06 / 01 / 2007$ & 16.0 & 100.622 & 335.5 & 243.5 & 73 & 18.4 & 5 & 9.5 & 3 \\
\hline & 7 & $22 / 01 / 2007$ & 16.0 & 0.014 & 0.8 & $0.6^{*}$ & $72^{*}$ & 0.1 & 7 & $0.0^{*}$ & $3^{*}$ \\
\hline & 8 & $07 / 02 / 2007$ & 16.0 & 0.028 & 1.0 & $0.7^{*}$ & $72^{*}$ & $0.1^{*}$ & $11^{*}$ & $0.0^{*}$ & $2^{*}$ \\
\hline & 9 & $23 / 02 / 2007$ & 16.0 & 0.012 & 0.6 & $0.4^{*}$ & $72^{*}$ & $0.1^{*}$ & $11^{*}$ & $0.0^{*}$ & $2^{*}$ \\
\hline & 10 & $11 / 03 / 2007$ & 16.0 & 0.021 & 0.6 & $0.4^{*}$ & $72^{*}$ & $0.1^{*}$ & $11^{*}$ & $0.0^{*}$ & $2^{*}$ \\
\hline & 11 & $27 / 03 / 2007$ & 16.0 & 7.500 & 33.0 & 22.8 & 69 & 3.8 & 12 & 1.1 & 3 \\
\hline & 12 & $12 / 04 / 2007$ & 16.0 & 0.030 & 1.8 & $1.2^{*}$ & $69^{*}$ & 0.8 & 43 & 0.1 & 4 \\
\hline & 13 & $28 / 04 / 2007$ & 16.0 & 0.106 & 6.2 & $4.3^{*}$ & $69^{*}$ & 4.1 & 67 & 0.1 & 2 \\
\hline & 14 & $14 / 05 / 2007$ & 16.0 & 0.010 & 0.7 & $0.5^{*}$ & $69^{*}$ & $0.3^{*}$ & 51 & $0.0^{*}$ & $3^{*}$ \\
\hline & 15 & $30 / 05 / 2007$ & 16.0 & 0.013 & 0.5 & $0.4^{*}$ & $69^{*}$ & $0.3^{*}$ & $51^{*}$ & $0.0^{*}$ & $3^{*}$ \\
\hline & 16 & $18 / 06 / 2007$ & 23.0 & 0.420 & 9.0 & $6.2^{*}$ & $69^{*}$ & 3.9 & 43 & 0.3 & 3 \\
\hline & 17 & $11 / 07 / 2007$ & 23.0 & 0.005 & 0.3 & $0.2^{*}$ & $69^{*}$ & $0.2^{*}$ & $43^{*}$ & $0.0^{*}$ & $3^{*}$ \\
\hline & 18 & 03/08/2007 & 23.0 & 0.001 & 0.2 & $0.2^{*}$ & $69^{*}$ & $0.1^{*}$ & $43^{*}$ & $0.0^{*}$ & $3^{*}$ \\
\hline & 19 & $23 / 08 / 2007$ & 16.0 & 0.001 & 0.1 & $0.1^{*}$ & $69^{*}$ & $0.0^{*}$ & $43^{*}$ & $0.0^{*}$ & $3^{*}$ \\
\hline & 20 & $08 / 09 / 2007$ & 16.0 & 0.140 & 4.2 & $2.9^{*}$ & $69^{*}$ & 1.9 & 45 & 0.1 & 3 \\
\hline & 21 & $24 / 09 / 2007$ & 16.0 & 0.067 & 3.1 & $2.2^{*}$ & $69^{*}$ & 1.3 & 42 & 0.2 & 6 \\
\hline
\end{tabular}

* Component fluxes representing intervals for which insufficient material was available for component measurement and were estimated.

ered for relative abundance calculations due to their negligible diatom content. The resulting counts yielded estimates of specimens $\mathrm{m}^{-2} \mathrm{~d}^{-1}$ according to Sancetta and Calvert (1988) and Romero et al. (2009), as well as relative abundances of diatom taxa.

\subsection{Taxonomic identifications}

All diatom and silicoflagellate specimens were identified to the lowest taxonomic level possible. Radiolarians were only identified to group level. Scanning electron microscope imagery was used on selected samples to verify taxonomic identifications made with the light microscope. Taxonomy followed modern concepts in Hasle and Syvertsen (1997). The resting spores of members of the subgenus Hyalochaete of the genus Chaetoceros were identified only at group level due to a lack of morphological criteria. The differentiation between Pseudo-nitzschia lineola and Pseudo-nitzschia turgiduloides was often difficult due to their state of preservation in the samples; therefore, they were grouped under the category Pseudo-nitzschia cf.lineola in this study. A species or group of species of the genus Thalassiosira larger than $20 \mu \mathrm{m}$, highly dissolved and with radial to fasciculated areolation were grouped together under the name Thalassiosira sp. 1. Several small Thalassiosira species with similar morphological features were assembled together under Thalassiosira trifulta group following Shiono and Koizumi (2000). Due to the gradational nature of the morphology between Thalassiosira gracilis var. gracilis and T. gracilis var. expecta, both varieties were grouped together under the name T. gracilis group following the recommendations of Crosta et al. (2005).

\subsection{Statistical analysis}

In order to enable comparison with other sites, annual flux estimates are provided in Table 3 . These were obtained by assuming that total mass flux outside of the sampling period was constant and by linearly interpolating values for the small gaps (i.e. 8.5-17 days intervals) during the productive season. No attempt was made to annualise the relative contribution of the diatom taxa, and therefore average values of the integrated diatom assemblage for whole sampling interval are provided in Table 3 .

In order to investigate the covariability between the main diatom taxa along our sediment trap records, we conducted separate principal component analyses (PCA) for each site using of Statistica $7.0^{\circledR}$ software. PCA analysis is a statis- 
Table 3. Estimated annual export fluxes of total mass flux, biogenic silica, calcium carbonate, POC and diatom valves for $<1 \mathrm{~mm}$ fraction at the 47,54 and $61^{\circ} \mathrm{S}$ sites.

\begin{tabular}{|c|c|c|c|c|c|c|}
\hline \multicolumn{7}{|c|}{ (a) Annual fluxes of biogeochemical components $\left(\mathrm{g} \mathrm{m}^{-2} \mathrm{yr}^{-1}\right)$ and diatom valves (valves $\left.10^{8} \mathrm{~m}^{-2} \mathrm{yr}^{-1}\right)$. } \\
\hline Trap & Year & Total mass flux & $\mathrm{SiO}_{2}$-biogenic & $\mathrm{PIC}$ as $\mathrm{CaCO}_{3}$ & POC & Diatom valves $\left(\times 10^{8}\right)$ \\
\hline \multirow[t]{3}{*}{ 47_1000 } & 1999-2000 & 12 & 1 & 8 & 1.1 & 0.3 \\
\hline & 2000-2001 & 15 & 1 & 12 & 0.9 & 0.8 \\
\hline & Average \pm SD & $14 \pm 2$ & $1 \pm 0$ & $10 \pm 3$ & $1.0 \pm 0.1$ & $0.5 \pm 0.4$ \\
\hline \multirow[t]{7}{*}{ 54_800 } & 1997-1998 & 19 & 10 & 4 & 0.6 & 30.2 \\
\hline & 1999-2000 & 52 & 31 & 9 & 1.4 & 29.1 \\
\hline & 2002-2003 & 30 & 16 & 8 & 1.1 & 39.0 \\
\hline & 2003-2004 & 20 & 12 & 4 & 0.6 & 22.5 \\
\hline & 2005-2006 & 29 & 15 & 9 & 0.7 & 30.8 \\
\hline & 2006-2007 & 16 & 10 & 2 & 0.5 & 34.5 \\
\hline & Average \pm SD & $24 \pm 13$ & $12 \pm 9$ & $7 \pm 3$ & $0.8 \pm 0.4$ & $31.0 \pm 5.5$ \\
\hline 61_2000 & 2001-2002 & 85 & 65 & 6 & 1.2 & 242.9 \\
\hline
\end{tabular}

(b) Proportion of biogeochemical components (wt \%).

\begin{tabular}{llccc}
\hline Trap & Year & $\mathrm{SiO}_{2}$-biogenic & PIC as $\mathrm{CaCO}_{3}$ & POC \\
\hline \multirow{2}{*}{$47 \_1000$} & $1999-2000$ & 8 & 65 & 9.0 \\
& $2000-2001$ & 7 & 76 & 5.6 \\
& Average $\pm \mathrm{SD}$ & $7 \pm 1$ & $70 \pm 8$ & $7.3 \pm 2.4$ \\
\hline $54 \_800$ & $1997-1998$ & 53 & 23 & 2.9 \\
& $1999-2000$ & 60 & 17 & 2.7 \\
& $2002-2003$ & 52 & 25 & 3.5 \\
& $2003-2004$ & 59 & 20 & 3.1 \\
& $2005-2006$ & 53 & 30 & 2.5 \\
& $2006-2007$ & 63 & 12 & 3.3 \\
& Average $\pm \mathrm{SD}$ & $57 \pm 4$ & $21 \pm 7$ & $3.0 \pm 0.4$ \\
\hline 612000 & $2001-2002$ & 76 & 7 & 1.4 \\
\hline
\end{tabular}

(c) Annual fluxes of biogeochemical elements, $\mathrm{mmol} \mathrm{m}^{-2} \mathrm{yr}^{-1}$ and mole ratios.

\begin{tabular}{llccccc}
\hline Trap & Year & BSi & PIC & POC & BSi : PIC & POC: BSi \\
\hline \multirow{2}{*}{$47 \_1000$} & 1999-2000 & 15 & 76 & 89 & 0.2 & 5.7 \\
& 2000-2001 & 17 & 116 & 72 & 0.1 & 4.2 \\
& Average \pm SD & $16 \pm 1$ & $96 \pm 28$ & $80 \pm 12$ & $0.2 \pm 0.0$ & $4.9 \pm 1.1$ \\
\hline 54_800 & $1997-1998$ & 168 & 43 & 46 & 3.9 & 0.3 \\
& $1999-2000$ & 513 & 87 & 117 & 5.9 & 0.2 \\
& $2002-2003$ & 264 & 77 & 89 & 3.4 & 0.3 \\
& $2003-2004$ & 192 & 40 & 50 & 4.8 & 0.3 \\
& $2005-2006$ & 252 & 87 & 59 & 2.9 & 0.2 \\
& 2006-2007 & 168 & 19 & 43 & 8.9 & 0.3 \\
& Average \pm SD & $259 \pm 131$ & $59 \pm 29$ & $67 \pm 29$ & $5.0 \pm 2.2$ & $0.3 \pm 0.0$ \\
\hline \multirow{2}{*}{$61 \_2000$} & $2001-2002$ & 1081 & 63 & 102 & 17.3 & 0.1 \\
\hline
\end{tabular}


tical technique that reduces the information brought by a high number of independent variables into a smaller set of dimensions (factors) with a minimum loss of information. Only species and taxonomic groups with relative contributions $>1 \%$ for the entire sampling period were considered in the analysis, i.e. thirteen taxa from site $47^{\circ} \mathrm{S}$ and nine taxa from site $54^{\circ} \mathrm{S}$. The relative contribution of these groups of species was recalculated for each sample and then a log transformation $(\log x+1)$ was applied in order to normalise the distribution of the data. Diatom groups were then determined using a Q-mode factor analysis of the samples with a maximised variance (VARIMAX) rotation.

The Shannon's diversity index (Shannon, 1949) was used to document latitudinal diversity trends across sites (Table 4).

\subsection{Environmental variables}

Weekly SSTs for the decade 1997-2007 were derived from the IGOSS NMC (the Integrated Global Ocean Services System Products Bulletin, National Meteorological Center; Reynolds et al., 2002) database, each value is a weekly composite of data collected within the area $48.5-45.5^{\circ} \mathrm{S} \times 130$ $150^{\circ} \mathrm{E}$ for the $47^{\circ} \mathrm{S}$ site and $55.5-52.5^{\circ} \mathrm{S} \times 130-150^{\circ} \mathrm{E}$ for the $54^{\circ} \mathrm{S}$ site (Figs. 2a and 3a). Sea-viewing Wide Field-ofView Sensor (SeaWiFS) satellite-derived chlorophyll $a$ and photosynthetically available radiation (PAR) estimates were obtained from NASA's Giovanni online data system (Acker and Leptoukh, 2007) for the same area used for the SST estimates (Figs. 2a and 3a).

Primary productivity values $\left(\mathrm{mg} \mathrm{C} \mathrm{m}^{-2} \mathrm{~d}^{-1}\right)$ for all the sites were obtained from the Ocean Productivity website (www.science.oregonstate.edu/ocean.productivity/index.

php), which provides estimates of net primary productivity derived from SeaWiFS satellite data by the standard vertically generalized production model (VGPM; Behrenfeld and Falkowski, 1997) and the carbon-based production model (CbPM; Behrenfeld et al., 2005).

\section{Results}

Here, we present the chemical (total mass, biogenic silica, carbonate and POC) and biological (diatom species) compositions of the particle fluxes registered at $\sim 1000 \mathrm{~m}$ at the $47^{\circ} \mathrm{S}$ site during 2 years (July 1999-October 2001) and at $54^{\circ} \mathrm{S}$ site during 6 years (September 1997-February 1998, July 1999-August 2000, November 2002-October 2004 and December 2005-October 2007; Table 2). A description of the total particle flux and its chemical signature at stations 47 and $54^{\circ} \mathrm{S}$ for the first year deployment of the sediment traps (1997-1998) can be found in Trull et al. (2001).

\subsection{Biogeochemical fluxes}

The total mass and bulk component (biogenic silica, carbonate and POC) fluxes for both traps are shown in Figs. 2b and $3 \mathrm{~b}$ and listed in Table 2 . Annual total mass flux at $\sim 1 \mathrm{~km}$ depth was the lowest at station $47^{\circ} \mathrm{S}\left(14 \pm 2 \mathrm{~g} \mathrm{~m}^{-2} \mathrm{yr}^{-1}\right.$; 2year average \pm standard deviation) and the highest at station $54^{\circ} \mathrm{S}\left(24 \pm 13 \mathrm{~g} \mathrm{~m}^{-2} \mathrm{yr}^{-1}\right.$; 6-year average \pm standard deviation; Table 3). BSi flux followed a similar latitudinal trend with lower fluxes at $47^{\circ} \mathrm{S}\left(1 \pm 0 \mathrm{~g} \mathrm{~m}^{-2} \mathrm{yr}^{-1}\right)$ compared to $54^{\circ} \mathrm{S}\left(12 \pm 9 \mathrm{~g} \mathrm{~m}^{-2} \mathrm{yr}^{-1}\right)$. Carbonate export exhibited less variability between sites, with values somewhat higher at $47^{\circ} \mathrm{S}\left(10 \pm 3 \mathrm{~g} \mathrm{~m}^{-2} \mathrm{yr}^{-1}\right)$ than those measured at $54^{\circ} \mathrm{S}\left(7 \pm 3 \mathrm{~g} \mathrm{~m}^{-2} \mathrm{yr}^{-1}\right.$, respectively). Interestingly, despite the strong latitudinal differences in the magnitude of the mass fluxes, POC export was very similar at both stations $\left(1.0 \pm 0.1\right.$ and $0.8 \pm 0.4 \mathrm{~g} \mathrm{~m}^{-2} \mathrm{yr}^{-1}$, for 47 and $54^{\circ} \mathrm{S}$, respectively).

In terms of relative abundance, the biogenic silica fraction represented $57 \%$ of the mass flux at the $54^{\circ} \mathrm{S}$ site, whereas its contribution dramatically dropped to $7 \%$ at the $47^{\circ} \mathrm{S}$ station. Calcium carbonate and POC accounted for 70 and $7.3 \%$ at the $47^{\circ} \mathrm{S}$ site, respectively, and 21 and $3 \%$ at the $54^{\circ} \mathrm{S}$ station (Table 3). These differences were primarily driven by the northward decrease in the biogenic silica fluxes. The $\mathrm{BSi}$ : PIC mole ratios decreased northward mirroring the latitudinal variations of the particle composition, from 5.0 at station $54^{\circ} \mathrm{S}$ to 0.2 at station $47^{\circ} \mathrm{S}$ (Table 3; Fig. S1 in the Supplement). The POC:BSi followed an opposite pattern with 0.3 at 54 and 4.9 at $47^{\circ} \mathrm{S}$.

The seasonality of the total mass flux at station $47^{\circ} \mathrm{S}$ during the 2-year record showed a period of enhanced particle export in spring and secondary peaks in summer and autumn (Fig. 2b). The highest fluxes were registered in November-December $2000\left(92-176 \mathrm{mg} \mathrm{m}^{-2} \mathrm{~d}^{-1}\right)$, March $2001\left(105 \mathrm{mg} \mathrm{m}^{-2} \mathrm{~d}^{-1}\right)$ and October $1999\left(90 \mathrm{mg} \mathrm{m}^{-2} \mathrm{~d}^{-1}\right)$. Total mass flux at the $54^{\circ} \mathrm{S}$ site was strongly seasonal with maximum values occurring during the late spring-summer and very low export prevailing through the autumn and winter months. The late spring-summer export maxima were as short as 3 months and often showed a bimodal distribution (e.g. 1997-1998, 1999-2000, 2002-2003; Fig. 3b). The highest total mass fluxes at this site were collected during December-January 1999 (511-724 $\left.\mathrm{mg} \mathrm{m}^{-2} \mathrm{~d}^{-1}\right)$, January $2006\left(418 \mathrm{mg} \mathrm{m}^{-2} \mathrm{~d}^{-1}\right)$, February $2003\left(397 \mathrm{mg} \mathrm{m}^{-2} \mathrm{~d}^{-1}\right)$ and January $1998\left(396 \mathrm{mg} \mathrm{m}^{-2} \mathrm{~d}^{-1}\right)$.

\subsection{Diatom fluxes}

The biogenic silica flux at the 47 and $54^{\circ} \mathrm{S}$ site was composed of diatoms, silicoflagellates, radiolarians and a handful of skeletons of the dinoflagellate Actiniscus pentasterias. Diatom fluxes were 1 order of magnitude higher than those of silicoflagellates and radiolarians at the $47^{\circ} \mathrm{S}$ site, and 1 and 3 orders of magnitude higher, respectively, at the $54^{\circ} \mathrm{S}$ site. Consistent with the biogenic silica flux, diatoms were most numerous in the $54^{\circ} \mathrm{S}$ site with an annual flux of $31 \pm 5.5 \times 10^{8}$ valves $\mathrm{m}^{-2} \mathrm{yr}^{-1}$ (6-year average \pm standard 
Table 4. List of diatom species recorded in the sediment traps of the 47,54 and $61^{\circ} \mathrm{S}(2000 \mathrm{~m})$ sites along the $140^{\circ}$ E. Relative abundances $<0.1$ are represented by an asterisk $\left(^{*}\right)$, whereas the absence of a taxon in a given site is represented by an empty circle $(\bigcirc)$.

\begin{tabular}{|c|c|c|c|}
\hline Species & $\mathrm{SAZ}\left(47^{\circ} \mathrm{S}\right)$ & PFZ $\left(54^{\circ} \mathrm{S}\right)$ & $\mathrm{AZ}\left(61^{\circ} \mathrm{S}\right)$ \\
\hline Actinocyclus actinochilus (Ehrenberg) Simonsen & * & 0 & * \\
\hline Actinocyclus curvatulus Janisch & 0.3 & $*$ & 0 \\
\hline Actinocyclus exiguus Fryxell and Semina & * & $\bigcirc$ & 0 \\
\hline Actinocyclus octonarius Ehrenberg & $*$ & 0 & $\bigcirc$ \\
\hline Actinocyclus spp. & 0.6 & * & \\
\hline Alveus marinus (Grunow) Kaczmarska and Fryxell & * & $\bigcirc$ & $\bigcirc$ \\
\hline Asteromphalus hookeri Ehrenberg & * & 0.5 & 0.2 \\
\hline A. hyalinus Karsten & * & 0.2 & 0.2 \\
\hline A. parvulus Karsten & * & 0.1 & 0.2 \\
\hline Asteromphalus spp. & 0 & 0 & * \\
\hline Azpeitia tabularis (Grunow) Fryxell and Sims & 10.8 & 0.8 & 0.7 \\
\hline Chaetoceros aequatorialis var. antarcticus Manguin & 0 & 0.1 & * \\
\hline Ch. atlanticus Cleve & 0.1 & 0.5 & 0.2 \\
\hline Ch. dichaeta Ehrenberg & 0 & 0.6 & 0.1 \\
\hline Ch. peruvianus Brightwell & 0.1 & * & 0 \\
\hline Chaetoceros subgenus Hyalochaete spp. & 0.2 & 0.4 & 0.2 \\
\hline Chaetoceros subgenus Phaeoceros spp. & 0 & 0.1 & 0.2 \\
\hline Chaetoceros resting spores & 2.3 & 0.5 & 0.1 \\
\hline Cocconeis spp. & 0.2 & 0 & 0 \\
\hline Corethron sp. & * & $*$ & \\
\hline Cyclotella spp. & $*$ & $\bigcirc$ & 0 \\
\hline Dactyliosolen antarcticus Castracane & & & \\
\hline Diploneis bombus (Ehrenberg) Ehrenberg & $*$ & $\bigcirc$ & 0 \\
\hline Eucampia antarctica (Castracane) Mangin (summer form) & 0 & 0.3 & 0 \\
\hline E. antarctica (Castracane) Mangin (winter form) & * & * & 0.1 \\
\hline Fragilariopsis curta (Van Heurck) Hustedt & 0 & * & 0.6 \\
\hline F. cylindrus (Grunow) Krieger & O & * & 0.2 \\
\hline F. doliolus (Wallich) Medlin and Sims & 0.5 & $\bigcirc$ & 0 \\
\hline F. kerguelensis (O’Meara) Hustedt & 43 & 59.3 & 79.9 \\
\hline F. obliquecostata (van Heurck) Heiden & 0 & $*$ & $*$ \\
\hline F. pseudonana (Hasle) Hasle & $*$ & 3.1 & 2 \\
\hline F. rhombica (O’Meara) Hustedt & 0.4 & 2.3 & 0.9 \\
\hline F. ritscherii Hustedt & 0.4 & 0.1 & 0.1 \\
\hline F. separanda Hustedt & 0 & 0.1 & 2.1 \\
\hline$F$. cf. sublineata (Van Heurck) Heiden & 0 & 0 & * \\
\hline Fragilariopsis spp. & O & * & 0 \\
\hline Gyrosigma spp. & ○ & * & $\bigcirc$ \\
\hline Haslea trompii (Cleve) Simonsen & $\bigcirc$ & 0.1 & * \\
\hline Hemidiscus cuneiformis Wallich & 3.7 & 0 & $\bigcirc$ \\
\hline Navicula directa (Smith) Ralfs in Pritchard & 0 & 4.6 & 0.3 \\
\hline Nitzschia bicapitata Cleve & 2.8 & $*$ & $\bigcirc$ \\
\hline N. braarudii (Hasle) & 0.2 & $\bigcirc$ & 0 \\
\hline N. kolaczeckii Grunow & 0.6 & * & 0 \\
\hline N. sicula (Castracane) Hustedt var. bicuneata Grunow & 2 & * & 0.1 \\
\hline N. sicula (Castracane) Hustedt var. rostrata Hustedt & * & * & $\mathrm{O}$ \\
\hline Nitzschia spp. & * & * & 0 \\
\hline Paralia spp. & * & 0 & 0 \\
\hline Pleurosigma spp. & 0.2 & 0.1 & \\
\hline Porosira pseudodenticulata (Hustedt) Jousé & 0.1 & * & * \\
\hline Proboscia alata (Brightwell) Sundström & 0.1 & * & 0 \\
\hline P. inermis (Castracane) Jordan Ligowski & 0 & * & 0 \\
\hline Proboscia spp. & $*$ & * & $\bigcirc$ \\
\hline
\end{tabular}


Table 4. Continued.

\begin{tabular}{|c|c|c|c|}
\hline Species & $\mathrm{SAZ}\left(47^{\circ} \mathrm{S}\right)$ & $\operatorname{PFZ}\left(54^{\circ} \mathrm{S}\right)$ & $\mathrm{AZ}\left(61^{\circ} \mathrm{S}\right)$ \\
\hline Psammodiction panduriforme (Gregory) Mann & 0.1 & $\bigcirc$ & $\bigcirc$ \\
\hline Pseudo-nitzschia cf. lineola & * & 8.1 & 0.4 \\
\hline$P-n$. heimii Manguin & $*$ & 4.6 & * \\
\hline Pseudo-nitzschia spp. & * & $\bigcirc$ & 0.1 \\
\hline Rhizosolenia antennata (Ehrenberg) Brown f. antennata & $*$ & $*$ & $\bigcirc$ \\
\hline R. antennata (Ehrenberg) Brown f. semispina Sundström & 0.1 & * & O \\
\hline R. bergonii Peragallo & 1.8 & $*$ & $\bigcirc$ \\
\hline Rhizosolenia cf. costata & 0 & * & $\bigcirc$ \\
\hline R. curvata Zacharias & O & $*$ & $\bigcirc$ \\
\hline R. polydactyla Castracane f. polydactyla & $*$ & $*$ & \\
\hline Rhizosolenia sp. f. 1A (Armand et Zielinski) & $\bigcirc$ & $*$ & \\
\hline Rhizosolenia spp. & 0.2 & $*$ & 0.1 \\
\hline Roperia tesselata (Roper) Grunow & 3.2 & * & $\bigcirc$ \\
\hline Stellarima stellaris (Roper) Hasle et Sims & 0.5 & $*$ & $\bigcirc$ \\
\hline Thalassionema nitzschioides var. capitulata (Castracane) Moreno-Ruiz & $*$ & 0.2 & 0.1 \\
\hline T. nitzschioides var. lanceolata (Grunow) Pergallo et Pergallo & 0.2 & 0.9 & 0.1 \\
\hline T. nitzschioides var. parvum Moreno-Ruiz & $*$ & $*$ & $\bigcirc$ \\
\hline T. nitzschioides var. 1 (Zielinski et Gersonde) & 0.2 & 0.4 & $\bigcirc$ \\
\hline Thalassiosira eccentrica (Ehrenberg) Cleve & 0.9 & 0.1 & 0.2 \\
\hline T. ferelineata Hasle and Fryxell & 0.3 & $\bigcirc$ & $\bigcirc$ \\
\hline T. gracilis var. expecta (Van Landingham) Frxyell et Hasle & 0.1 & 0.7 & 0.4 \\
\hline T. gracilis var. gracilis (Karsten) Hustedt & 0.3 & 3.9 & 3.6 \\
\hline T. gracilis group & 0.3 & 4.6 & 4.1 \\
\hline T. gravida Cleve & $\bigcirc$ & $\bigcirc$ & * \\
\hline T. lentiginosa (Janisch) Fryxell & 2.1 & 2.1 & 5 \\
\hline T. leptopus (Grunow ex Van Heurck) Hasle et G.Fryxell & O & $\bigcirc$ & * \\
\hline T. lineata Jousé & 2.2 & $\bigcirc$ & $\bigcirc$ \\
\hline T. maculata Fryxell et Johans. & 0.2 & 0.1 & * \\
\hline T. oestrupii (Ostenfeld) Hasle var. oestrupii Fryxell and Hasle & 3.6 & 0.3 & * \\
\hline T. oestrupii (Ostenfeld) Hasle var.venrickae Fryxell and Hasle & 0.6 & 0.1 & $\bigcirc$ \\
\hline T. oliveriana(O’Meara) Makarova et Nikolaev & 0.1 & 0.6 & 0.7 \\
\hline T. symmetrica Fryxell et Hasle & 0.3 & $*$ & $\bigcirc$ \\
\hline T. trifulta Fryxell & 0.1 & $\bigcirc$ & $\bigcirc$ \\
\hline T. tumida (Janisch) Hasle & 0.2 & 0.3 & 0.1 \\
\hline Thalassiosira sp. 1 & 5.4 & 0.1 & * \\
\hline Thalassiosira sp. 2 & 0.2 & 0.1 & $\bigcirc$ \\
\hline Thalassiosira sp. 3 & O & 0.2 & $\bigcirc$ \\
\hline Thalassiosira eccentric group & 0.1 & $\bigcirc$ & $\bigcirc$ \\
\hline T. linear group & 0.2 & $*$ & 0.1 \\
\hline T. trifulta group & 1.9 & 0.1 & $\bigcirc$ \\
\hline Thalassiosira spp. $<20 \mu \mathrm{m}$ & 0.9 & 1.4 & 0.4 \\
\hline Thalassiosira spp. $>20 \mu \mathrm{m}$ & 1.7 & 0.1 & * \\
\hline Thalassiothrix antarctica Schimper ex Karsten & 2.2 & 0.4 & 0.2 \\
\hline Trachyneis aspera (Ehrenberg) Cleve & $\bigcirc$ & $\bigcirc$ & $\bigcirc$ \\
\hline Trichotoxon reinboldii (Van Heurck) Reid et Round & 0 & $*$ & $\bigcirc$ \\
\hline Tropidoneis group & $*$ & 0.4 & \\
\hline Other centrics & 1.2 & 0.1 & $*$ \\
\hline Other pennates & 0.2 & $*$ & 0.1 \\
\hline Shannon's diversity index & 2.48 & 1.86 & 1.04 \\
\hline
\end{tabular}

deviation) compared to $0.5 \pm 0.4 \times 10^{8}$ valves $\mathrm{m}^{-2} \mathrm{yr}^{-1}$ (2year average \pm standard deviation) of the $47^{\circ} \mathrm{S}$ site.

Total diatom-valve flux at the $47^{\circ} \mathrm{S}$ site (Fig. 4a) showed a less pronounced seasonality than that observed at $54^{\circ} \mathrm{S}$
(Fig. 5a) and exhibited a weak correlation with the total mass $(r=0.37, n=30)$ and BSi $(r=0.42, n=29)$ fluxes. Diatoms occurred in the greatest numbers during November $2000\left(1.6 \times 10^{6}\right.$ valves $\left.\mathrm{m}^{-2} \mathrm{~d}^{-1}\right)$, February- 

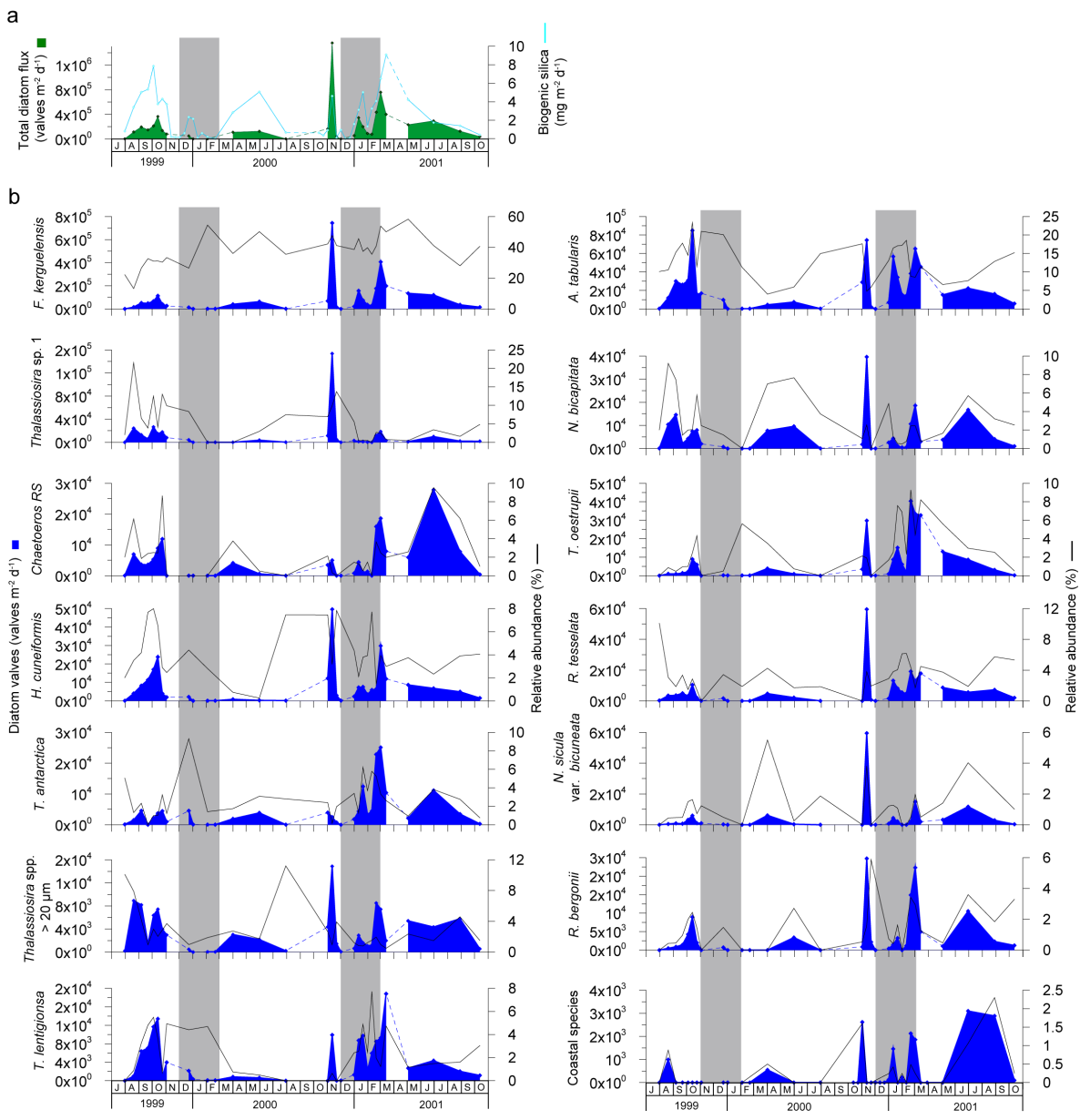

Figure 4. Temporal variability of (a) total diatom flux and biogenic silica and (b) flux and relative contribution of the main diatom species at $1000 \mathrm{~m}$ at the $47^{\circ} \mathrm{S}$ site for the period July 1999-October 2001.

March $2001\left(0.4-0.8 \times 10^{6}\right.$ valves $\left.\mathrm{m}^{-2} \mathrm{~d}^{-1}\right)$ and October $1999\left(0.4 \times 10^{6}\right.$ valves $\left.\mathrm{m}^{-2} \mathrm{~d}^{-1}\right)$.

At station $54^{\circ} \mathrm{S}$, total diatom-valve flux was highly seasonal and followed a similar pattern to that of the total mass $(r=0.66, n=108)$ and BSi fluxes $(r=0.68, n=108)$. These correlations are high despite the biases associated with our diatom-valve counting technique which does not allow for quantification of small valve fragments. In particular the high diatom-valve fragmentation observed during the productive period of 1999-2000 reduced the correlations between diatom-valve flux and total mass and BSi fluxes. In fact, the latter correlations increased significantly after excluding the 1999-2000 data $(r=0.85, n=88$ and $r=0.87$, $n=88$, respectively).

The spring-summer diatom bloom often exhibited two peaks of enhanced export separated by a period of lower flux (e.g. 1997-1998, 1999-2000, 2002-2003; Figs. 5a and 7). During the productive period of 2006-2007, the diatom bloom exhibited one single peak during which the largest diatom fluxes of the record were regis- tered (up to $100 \times 10^{6}$ valves $\mathrm{m}^{-2} \mathrm{~d}^{-1}$ in January 2007 ; Fig. 5a). Secondary diatom flux maxima were registered in January $1998\left(71 \times 10^{6}\right.$ valves $\left.\mathrm{m}^{-2} \mathrm{~d}^{-1}\right)$, December $2002\left(65 \times 10^{6}\right.$ valves $\left.\mathrm{m}^{-2} \mathrm{~d}^{-1}\right)$ and December 1999 $\left(52 \times 10^{6}\right.$ valves $\left.\mathrm{m}^{-2} \mathrm{~d}^{-1}\right)$. We noticed that during the 19992000, summer bloom the high BSi fluxes were not coupled with a proportional increase of the diatom valves (Fig. 5a). The higher degree of fragmentation observed on these samples could be attributed to either a more intense grazing pressure by the zooplankton community that year or by a higher fragmentation of the valves during the sample preparation due to the presence of abundant numbers of weakly silicified diatoms (e.g. species of the genus Pseudo-nitzschia) which are more prone to break during the sample processing (Rembauville et al., 2015).

In terms of diatom assemblage composition, the occurrence and fractional contributions of all the diatom taxa found at the 47 and $54^{\circ} \mathrm{S}$ study sites, as well as at $61^{\circ} \mathrm{S}$ (Rigual-Hernández et al., 2015), are provided in Table 4. The diatom sinking assemblage at station $47^{\circ} \mathrm{S}$ was more 


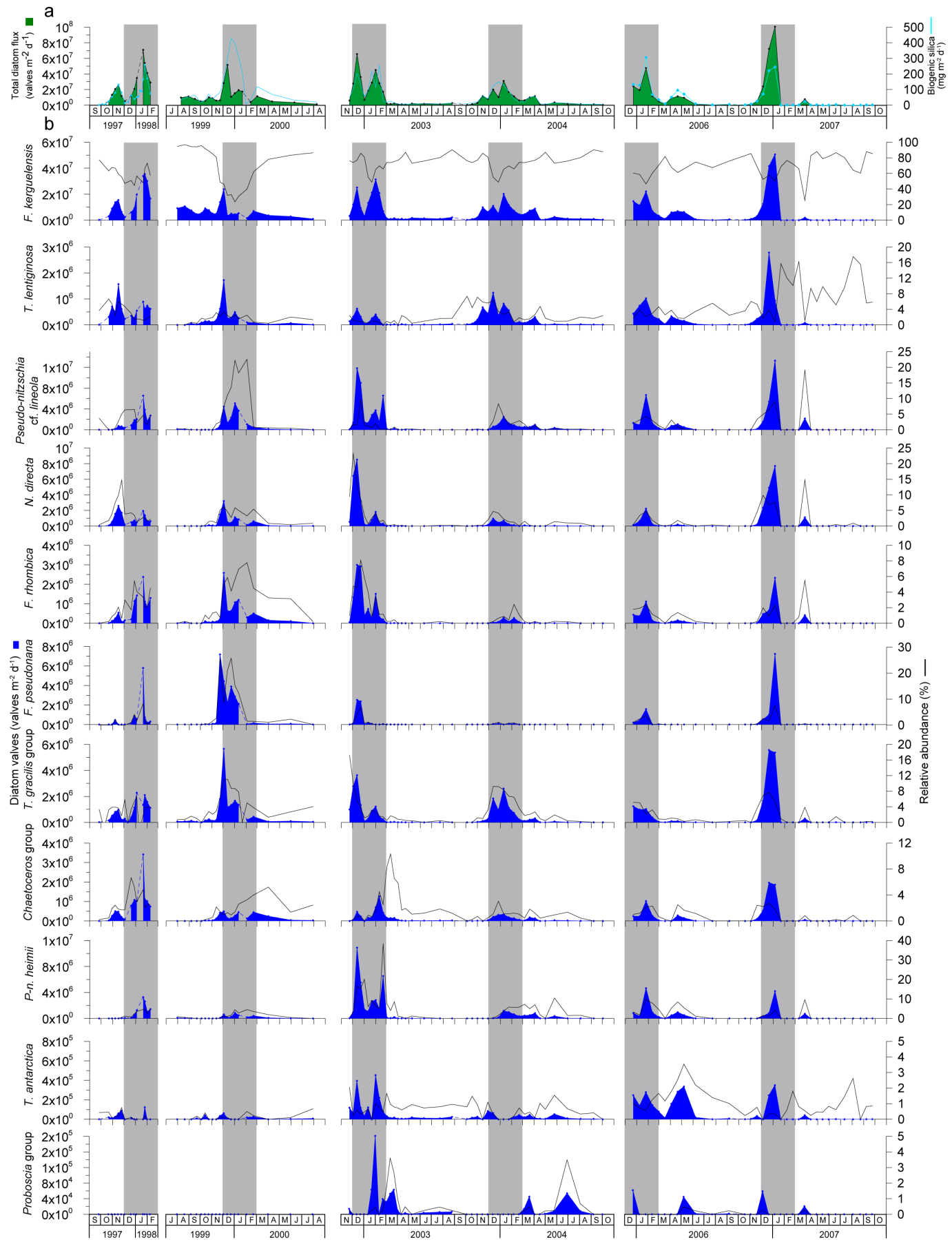

Figure 5. Temporal variability of (a) total diatom flux and biogenic silica and (b) flux and relative contribution of the main diatom species at $800 \mathrm{~m}$ at the $54^{\circ} \mathrm{S}$ site for the periods July 1999-August 2000, November 2002-October 2004 and December $2005-O c t o b e r 2007$. 
Table 5. Varimax loadings matrix (rotation: varimax normalised). Factor loadings for analysis on sediment trap samples using species and group of species with abundances higher than $1 \%$ of the total integrated diatom assemblage for the whole sampling period at the $47^{\circ} \mathrm{S}$ (a) and $54^{\circ} \mathrm{S}$ site (b). Bold print indicates the dominant species or group of species within each factor (loadings $>0.70$ ).

\begin{tabular}{|c|c|c|c|c|}
\hline \multicolumn{5}{|c|}{ (a) $47^{\circ} \mathrm{S}$ site. } \\
\hline & Factor 1 & Factor 2 & Factor 3 & Factor 4 \\
\hline Fragilariopsis kerguelensis & 0.05 & -0.73 & -0.46 & -0.35 \\
\hline Azpeitia tabularis & 0.59 & 0.38 & 0.06 & 0.55 \\
\hline Thalassiosira sp. 1 & -0.11 & 0.91 & -0.17 & -0.21 \\
\hline Nitzschia bicapitata & -0.82 & 0.41 & 0.09 & 0.19 \\
\hline Chaetoceros resting spores & -0.59 & 0.12 & 0.56 & 0.08 \\
\hline Thalassiosira oestrupii var. oestrupii & -0.06 & -0.75 & 0.20 & 0.13 \\
\hline Hemidiscus cuneiformis & 0.63 & 0.47 & 0.03 & -0.09 \\
\hline Roperia tesselata & 0.04 & -0.29 & 0.73 & 0.11 \\
\hline Thalassiothrix antarctica & 0.06 & -0.05 & 0.05 & 0.61 \\
\hline Nitzschia sicula var. bicuneata & -0.64 & -0.09 & -0.03 & \\
\hline Thalassiosira lineata & 0.15 & 0.02 & 0.78 & -0.39 \\
\hline Rhizosolenia bergonii & 0.08 & 0.14 & 0.17 & -0.57 \\
\hline Thalassiosira lentiginosa & 0.47 & -0.16 & 0.15 & 0.29 \\
\hline Thalassiosira trifulta group & -0.53 & -0.04 & -0.06 & -0.57 \\
\hline Variance $(\%)$ & 19 & 19 & 13 & 13 \\
\hline Cumulative variance & 19 & 38 & 51 & 64 \\
\hline
\end{tabular}

(b) $54^{\circ} \mathrm{S}$ site.

\begin{tabular}{lrrr}
\hline Diatom species or groups of species & Factor 1 & Factor 2 & Factor 3 \\
\hline Fragilariopsis kerguelensis & $-\mathbf{0 . 9 1}$ & -0.20 & -0.11 \\
Navicula directa & $\mathbf{0 . 8 4}$ & -0.14 & 0.17 \\
Pseudo-nitzschia heimii & 0.35 & $\mathbf{0 . 7 0}$ & 0.36 \\
Pseudo-nitzschia cf. lineola & $\mathbf{0 . 7 7}$ & 0.25 & 0.41 \\
Thalassiosira gracilis group & $\mathbf{0 . 8 1}$ & -0.19 & 0.19 \\
Fragilariopsis pseudonana & $\mathbf{0 . 7 9}$ & 0.09 & -0.08 \\
Fragilariopsis rhombica & $\mathbf{0 . 8 5}$ & 0.29 & 0.14 \\
Thalassiosira lentiginosa & 0.09 & $\mathbf{- 0 . 8 9}$ & 0.00 \\
Chaetoceros group & 0.12 & 0.12 & $\mathbf{0 . 9 3}$ \\
Variance (\%) & 48 & 17 & 14 \\
Cumulative total variance (\%) & 48 & 65 & 79 \\
\hline
\end{tabular}

Bold values highlight the taxa that define each factor.

diversified $\left(H^{\prime}\right.$ for the entire sampling period $\left.=2.48\right)$ than those found south the $\operatorname{SAF}\left(H^{\prime}=1.86\right.$ at the $54^{\circ} \mathrm{S} ; H^{\prime}=1.04$ at the $61^{\circ} \mathrm{S}$ ) consisting of 79 species or groups of species. The most abundant species was Fragilariopsis kerguelensis, which represented $43 \%$ of the integrated assemblage for the entire sampling period (Fig. 4). Subordinate contributions to the diatom assemblage were made by Azpeitia tabularis (10\%), Thalassiosira sp. 1 (4\%), Nitzschia bicapitata (4\%), resting spores of Chaetoceros spp. (subgenus Hyalochaetae; $3 \%$ ), Thalassiosira oestrupii var. oestrupii (3\%), Hemidiscus cuneiformis (3\%) and Roperia tesselata (3\%; Fig. 4). A total of 77 taxa were identified at the $54^{\circ} \mathrm{S}$ site (Table 4). $F$. kerguelensis was also the dominant species, contributing up to $59 \%$ of the diatom assemblage for the whole sampling period (Fig. 5). Secondary contributors correspond to Pseudonitzschia cf. lineola (8\%), Pseudo-nitzschia heimii (5\%),
Thalassiosira gracilis group (4\%), Fragilariopsis pseudonana (3\%), Fragilariopsis rhombica (2\%) and Thalassiosira lentiginosa (2\%; Fig. 5).

\subsection{Principal component analysis of diatom assemblages}

The PCA for the $47^{\circ} \mathrm{S}$ site identified four components containing $64 \%$ of the total variance, whereas that of the $54^{\circ} \mathrm{S}$ site required three components to describe $79 \%$ of the information of diatom data (Table 5). Figure 6 shows the position of the species on the first two PCA axes for the 47 and $54^{\circ} \mathrm{S}$ sites. Together with the species, we plotted total and major components mass fluxes.

The first component of the PCA for the $47^{\circ} \mathrm{S}$ site accounted for $19 \%$ of the variance. The centric species $A$. tab- 
ularis and H. cuneiformis (Fig. 6) had a positive loading on factor 1 and exhibited their highest relative abundance during spring and summer (Fig. 4). Factor 2 explained $19 \%$ of the variance and was dominated by $F$. kerguelensis, $T$. oestrupii var. oestrupii and Thalassiosira sp. 1. F. kerguelensis maintained a relatively constant contribution to the diatom assemblages during the whole sampling interval with a tendency to peak in late summer and autumn together with T. oestrupii var. oestrupii. None of the factors of the PCA of the $47^{\circ} \mathrm{S}$ site were significantly correlated with the biogenic particle fluxes (Fig. 6a and Table 6a).

At the $54^{\circ} \mathrm{S}$ site, the first component (48\% of the total variance) was highly correlated with the bulk components of the flux (Fig. 6b and Table 6b) and individualises two groups of diatom species. High-positive factor loadings characterise the bloom-forming Pseudo-nitzschia cf. lineola, F. rhombica, F. pseudonana and $N$. directa and the cool-openocean diatom $T$. gracilis group. The relative contribution of these species peaked during the productive season (Fig. 5) and showed a strong positive correlation with all the components of the flux (Fig. $6 \mathrm{~b}$ and Table 6b). Therefore, diatom species characterized by a high-positive first factor loading can be defined as the "high-export group". In contrast, a highnegative factor loading on the first PCA axis was attributed to F. kerguelensis, which peaked during winter and autumn, coinciding with very low particle fluxes. Pseudo-nitzschia heimii was the only species with a high positive factor loading on the second PCA axis (Fig. 6b and Table 5) and its relative abundance peaked mainly from mid-summer to autumn. With the exception of year 2002-2003, a consistent diatom species succession was consistently observed over the growth season at the $54^{\circ} \mathrm{S}$ site (Figs. $5 \mathrm{~b}$ and 7). During those years with a double peak diatom sedimentation bloom, the first maximum (November to early December) was always dominated by F. kerguelensis and by other large and heavily silicified diatoms, such as T. lentiginosa. During the second peak (in late December to early February), the relative contribution of Pseudo-nitzchia cf. lineola and small Fragilariopsis species increased sharply, representing together up to $50 \%$ of the diatom assemblage in January 2000 (Figs. 5b and 7). Even during year 2006-2007, when the diatom sedimentation bloom exhibited a single maximum, a similar succession can be discerned within the peak.

\section{Discussion}

\subsection{Latitudinal trend of biogenic particle fluxes to the ocean interior}

The contrasting latitudinal variations in the composition and magnitude of the particle fluxes along the $140^{\circ} \mathrm{E}$ transect reflect the physicochemical and biological characteristics of the different zonal systems sampled by the traps. Relatively low BSi and diatom export measured in the mesopelagic wa-
Table 6. Correlation coefficients between the PCA factors and the fluxes of bulk components (total mass, carbonate, biogenic silica and POC) for the $47^{\circ} \mathrm{S}$ (a) and $54^{\circ} \mathrm{S}$ (b) sites.

\begin{tabular}{lrrrr}
\hline \multicolumn{5}{c}{ (a) $47^{\circ} \mathrm{S}$ site. } \\
& Factor 1 & Factor 2 & Factor 3 & Factor 4 \\
\hline Total mass & -0.10 & -0.14 & 0.01 & -0.19 \\
Biogenic silica & -0.09 & -0.10 & 0.12 & -0.11 \\
Carbonate & -0.07 & -0.18 & -0.03 & -0.20 \\
POC & -0.28 & 0.06 & 0.14 & -0.12 \\
\hline & (b) $54^{\circ}$ S site. & & \\
\hline & Factor 1 & Factor 2 & Factor 3 & \\
\hline Total mass & $\mathbf{0 . 7 3}$ & 0.07 & 0.03 & \\
Biogenic silica & $\mathbf{0 . 7 1}$ & 0.08 & -0.01 & \\
Carbonate & 0.66 & 0.06 & 0.15 & \\
POC & $\mathbf{0 . 7 5}$ & 0.12 & 0.06 & \\
\hline
\end{tabular}

Bold values are significant at $p<0.05$.

ters of the SAZ (Fig. 8a and Table 3) are consistent with the low-to-moderate diatom biomass accumulation in the surface layer of this region (Kopczynska et al., 2001; de Salas et al., 2011). Low silicic acid (Bowie et al., 2011a) and iron levels (Sedwick et al., 2008; Bowie et al., 2009; Mongin et al., 2011), together with light limitation, as a result of cloudiness (Bishop and Rossow, 1991) and deep summer mixed layers (70-100 m; Rintoul and Trull, 2001), are considered the main factors responsible for the reduced diatom production in the SAZ. Moreover, the low BSi : PIC mole ratios measured by the traps $(<<1$; Table 3$)$ illustrate the relatively low contribution of diatoms to the particle flux export to the ocean interior. Low diatom export fluxes and $\mathrm{BSi}$ : PIC mole ratios are characteristic of carbonate-dominated and low-productivity regimes (Honjo et al., 2008) and typical of much of the circumpolar SAZ (Honjo et al., 2000; Trull et al., 2001a).

The higher diatom-valve fluxes and BSi export at the $54^{\circ} \mathrm{S}$ site (Table 3; Fig. 8a) agrees well with previous studies of the PFZ surface waters south of Tasmania, which reported relatively large and heavily silicified diatoms as major contributors to the phytoplankton biomass (Kopczynska et al., 2001; de Salas et al., 2011). Higher levels of silicic acid (Smith Jr et al., 2000), colder summer surface waters and shallower mixed winter layers than those of the SAZ (Rintoul and Trull, 2001) are most likely the main factors responsible for the greater prevalence of diatoms in this region. As a result of the enhanced diatom production and the drop in the abundance of calcifying phytoplankton (Findlay and Giraudeau, 2000; Honjo et al., 2000), BSi : PIC mole ratios of the settling material at this site shift to $>1$ (Table 3 ).

Further south, at station $61^{\circ} \mathrm{S}$ in the southern AZ, RigualHernández et al. (2015) documented an annual diatom flux 1 order of magnitude greater than that measured at the $54^{\circ} \mathrm{S}$ site $\left(243 \times 10^{8}\right.$ valves $\mathrm{m}^{-2} \mathrm{~d}^{-1}$ at $2000 \mathrm{~m}$; Table 3 and 

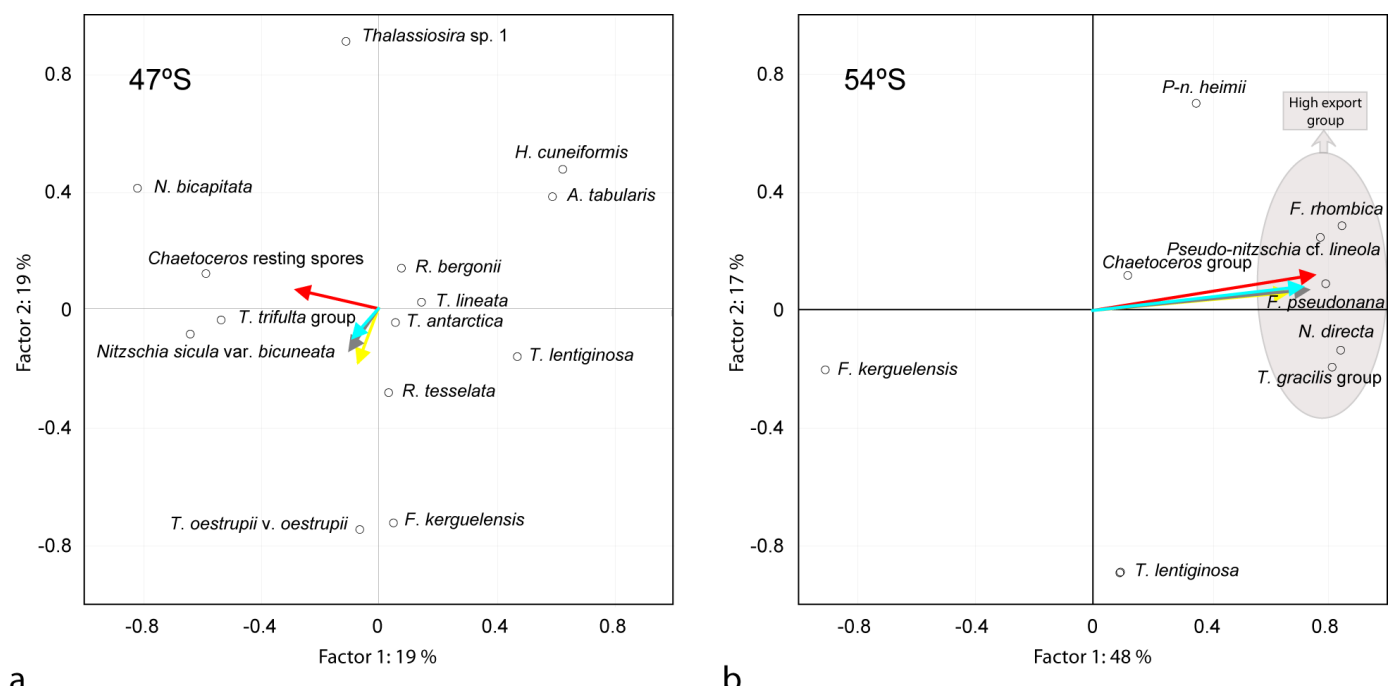

Figure 6. Principal component analysis for the PFZ $47^{\circ} \mathrm{S}$ (a) and SAZ $54^{\circ} \mathrm{S}$ sites (b). Projection of the variables (diatom species or groups of species accounting for more than $1 \%$ of the integrated assemblage for the whole sampling period) on the first two PCA axes together with total mass (grey), biogenic silica (blue), carbonate (yellow) and POC (red) flux.

Fig. 8a). The corresponding BSi export was as large as $65 \mathrm{~g} \mathrm{~m}^{-2} \mathrm{y}^{-1}$, a value very similar to that reported in the AZ south of New Zealand by Honjo et al. (2000; $57 \mathrm{~g} \mathrm{~m}^{-2}$, station MS-4; Fig. 1). These very high BSi fluxes are arguably the largest BSi exports ever measured in the world ocean (Honjo et al., 2008). Due to the upwelling of Circumpolar Deep Water (CDW) at the Antarctic Divergence, the surface waters of the southern AZ exhibit very high silicate concentrations (up to $70 \mathrm{mmol} \mathrm{Si} \mathrm{m}^{-3}$; Pollard et al., 2006) which enhance diatom growth at the expense of other phytoplankton groups (Mengelt et al., 2001; Selph et al., 2001). These high diatom export values are consistent with the large accumulation of diatom remains in the surface sediments between the polar front $(\mathrm{PF})$ and the winter sea ice edge that encircles Antarctica, the so-called diatom ooze belt (Burckle and Cirilli, 1987). This diatom ooze belt constitutes the single most important sink for silica in the world ocean (DeMaster, 1981; Ledford-Hoffman et al., 1986; Tréguer et al., 1995; Tréguer, 2014).

\subsection{Latitudinal diatom species distribution}

The species occurrence observed along the $140^{\circ} \mathrm{E}$ transect is consistent with previous reports on diatom assemblage composition in the surface waters (Kopczynska et al., 1986; Kopczynska et al., 2001; de Salas et al., 2011) and sediments (Armand et al., 2005; Crosta et al., 2005; Romero et al., 2005) of the Australian sector of the Southern Ocean, and provide evidence, once again, that the frontal systems represent natural physical boundaries for phytoplankton species distribution (Boyd, 2002).

Overall, the diatom assemblage registered at the $47^{\circ} \mathrm{S}$ site is typical of the SAZ and differs significantly from those found in the PFZ and AZ (Table 4). The SAZ represents a "buffer zone" between the subtropical gyres to the north and the polar waters to the south which results in a highly diverse diatom community as highlighted by the highest $H^{\prime}$ (2.48; Table 4) of the study transect. The occurrence of the warm water taxa H. cuneiformis, Fragilariopsis doliolus, Nitzschia kolaczeckii and T. lineata (Romero et al., 2005; Venrick et al., 2008) is restricted to this station, and therefore, these species appear as good indicators for the southward migration of the warmer, saltier and nutrient-poor water masses of the SAZ into the ACC. Moreover, the stark increase in the abundance of the open-ocean diatoms A. tabularis, N. bicapitata, $R$. tesselata and Thalassiosira oestrupii north of the SAF suggest the preference of these species for warmer waters (Hasle and Syvertsen, 1997; Romero et al., 2005).

The sinking diatom assemblage registered at the $54^{\circ} \mathrm{S}$ site is characteristic of the ACC waters and largely defined by the dominance of $F$. kerguelensis. The relative abundance of $F$. kerguelensis at the PFZ (59\%) represents a transitional value between that of the AZ (80\%) and that of the SAZ (43\%). This strong latitudinal gradient mirrors its distribution in the surface sediments, which has been previously tied to summer SST (Crosta et al., 2005; Esper et al., 2010). However, other potentially important influences such as mixed layer depth, seasonality, and iron and silicate abundance also exhibit latitudinal gradients, and therefore may also influence the distribution of this species. Peak abundances of Pseudonitzschia species along the $140^{\circ} \mathrm{E}$ transect are observed in the PFZ (Table 4) and are consistent with previous studies that described this genus as a major contributor to the bulk phytoplankton biomass in the ACC waters (e.g. Kopczynska et al., 2001; Smetacek et al., 2002; de Salas et al., 2011). Moreover, it is worth noting that $P-n$. heimii, together with 


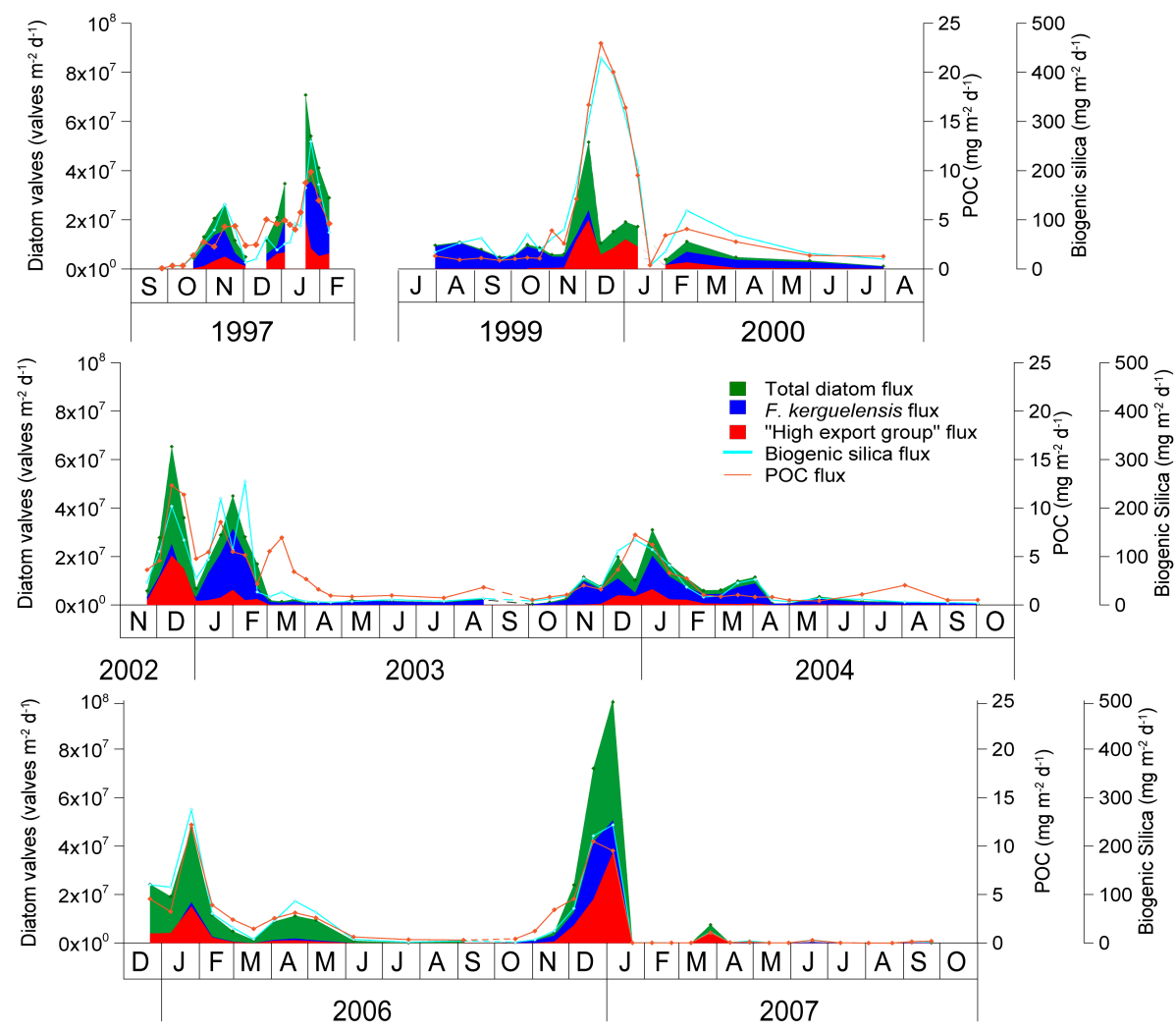

Figure 7. Temporal variability of the total diatom, "high-export group", Fragilariopsis kerguelensis, biogenic silica and POC fluxes for the 6-year record at the $54^{\circ} \mathrm{S}$ site.

other large diatoms (e.g. Thalassiothrix and Proboscia), have been reported to be major contributors of a SCM consistently observed between 53 and $58^{\circ} \mathrm{S}$ along $140^{\circ} \mathrm{E}$ (Kopczynska et al., 2001; Parslow et al., 2001). Navicula directa also showed maximum abundances at the PFZ site with values $\sim 5 \%$. This species has been traditionally described as a benthic-dwelling species (Scott and Marchant, 2005 and references therein) with an affinity for sea ice conditions (Armand, 1997). However, its persistent presence throughout the 6-year record and similar seasonal flux pattern to that of other well-known open-ocean species of the ACC, such as Thalassiosira gracilis group $(r=0.8, n=108$; Fig. $5 b)$, point to a pelagic distribution of this species. This concept agrees well with Kopczynska et al. (1986) and Waite and Nodder (2001), who documented Navicula populations of considerable abundance in areas remote from coastal and sea ice influence in the Australian sector.

Although in many aspects the composition of the diatom assemblage at the $61^{\circ} \mathrm{S}$ site was similar to that of station $54^{\circ} \mathrm{S}$, there were some qualitative and quantitative differences. As a result of the southward increase in the relative abundance of $F$. kerguelensis, the diversity $\left(H^{\prime}\right)$ and the relative contribution of most of the secondary constituents of the diatom assemblage at $61^{\circ} \mathrm{S}$ exhibited lower values than at $54^{\circ} \mathrm{S}$ (Table 4). For example, Pseudo-nitzchia species that represented cumulatively $13 \%$ of the integrated assemblage, dropped to $<1 \%$ at the $61^{\circ} \mathrm{S}$ site. Navicula directa followed a similar pattern with maximum abundances at $54^{\circ} \mathrm{S}(5 \%)$ and negligible fluxes at $61^{\circ} \mathrm{S}$. It is possible, however, that other factors, such as selective grazing or ecological constraints, may also account for the lower contribution of these species in the AZ.

\subsection{Seasonal variability of diatom assemblages}

Taking into account that diatoms are, by far, the main contributors to the $\mathrm{BSi}$ production at the $54^{\circ} \mathrm{S}$ site, and that the BSi fraction, in turn, dominated the total mass flux, the strong correlation between diatom-valve and mass fluxes $(r=0.85$; $n=88$ ) suggests that the particle export at the PFZ is mainly mediated by diatoms. In contrast, at the $47^{\circ} \mathrm{S}$ site, the silicapoor content of the particles and the low correlation between diatom-valve and mass fluxes $(r=0.37 ; n=30)$ indicates a minor role for diatoms in regulating the export in the SAZ. These results underscore the contrasting role that diatoms play in the controls on the flux north and south of the SAF (Trull et al., 2001a; Ebersbach et al., 2011).

The less defined seasonal pattern and lower amplitude of the diatom fluxes observed at the $47^{\circ} \mathrm{S}$ site (Fig. 4) are a reflection of the different algal community north of the 

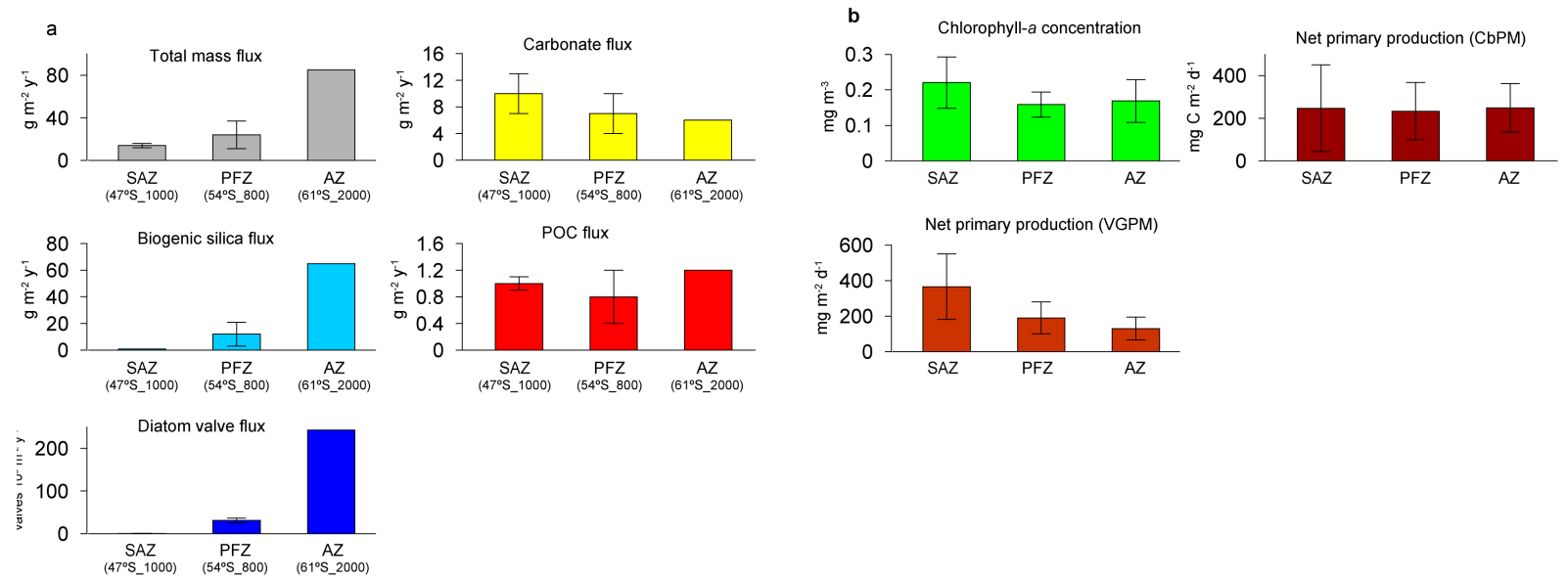

Figure 8. (a) Annual mean total mass, major component and diatom-valve fluxes for the $<1 \mathrm{~mm}$ particulate fraction for the 47,54 and $61^{\circ} \mathrm{S}$ sites. (b) Annual average of chlorophyll $a$ concentration and two different estimates of primary productivity (standard vertically generalized production model - VGPM; and carbon-based production model - CbPM) for the 47, 54 and $61^{\circ} \mathrm{S}$ sites from October 1997 to September 2007.

SAF, dominated by non-siliceous phytoplankton (Odate and Fukuchi, 1995; Kopczynska et al., 2001; de Salas et al., 2011). For both years of our study, the highest annual diatom export events coincided with the onset of the biomass accumulation in the surface waters, indicating that diatoms responded rapidly to the enhanced light levels (Fig. 2a) and to the formation of a stable and shallow mixed layer (Rintoul and Trull, 2001). However, unlike the chlorophyll $a$ concentration that gradually increased throughout the spring, diatom export rapidly returned to winter values most likely caused by the depletion of the winter silicate and/or iron stocks (Lannuzel et al., 2011). This seasonal pattern is characteristic of the SAZ and other silicate-poor environments, where diatoms typically bloom at the beginning of the successional sequence and then are replaced by other functional groups (Margalef, 1978; Balch, 2004; Alvain et al., 2008; RigualHernández et al., 2013). The increase in the diatom and BSi fluxes from January to early March 2001 suggests the export of a second diatom bloom that year. South of Tasmania the SAZ exhibits a complex physical structure with frequent wind mixing events (Yuan, 2004) and fronts meandering and forming eddies that can reach the trap location (Rintoul and Trull, 2001; Herraiz-Borreguero and Rintoul, 2011). Thus, it is likely that one of these mechanisms injected nutrients into the surface layer of the $47^{\circ} \mathrm{S}$ site fuelling diatom production and allowing the "reset" of phytoplankton succession. In terms of population dynamics, the seasonal succession of species at the $47^{\circ} \mathrm{S}$ site was not as clearly expressed as in station $54^{\circ} \mathrm{S}$ and none of the diatom species seem to play an important role in the export controls of any of the components of the flux as indicated by the results of the PCA (Fig. 6a). F. kerguelensis exhibited fairly constant relative abundances throughout the record suggesting little competition for resources with other diatom species. The temperate-to-warm water species $H$. cuneiformis and A. tabularis showed their maximum contribution at times of maximum diatom export which suggests that these species are the first to respond to nutrient supply in the surface waters in this region.

The annual export maxima of total mass and diatom-valve flux at $54^{\circ} \mathrm{S}$ were separated into two peaks for most of the years (Figs. 5a and 7). A similar double peak feature of the particle bloom has been previously reported in the AZ of the Pacific (Honjo et al., 2000; Grigorov et al., 2014) and Atlantic (Fischer et al., 2002). Honjo (2004) speculated that such a double peak structure may be due to a break in primary production caused by a temporary depletion of a limiting nutrient, while Grigorov et al. (2014) attributed the drop in the diatom flux between two periods of enhanced export to a storm event that mixed the diatom biomass out of the surface layer. The lack of accompanying in situ measurements of nutrient concentration and mixed layer depth precludes the direct assessment of these possibilities.

The initial diatom population size, species-specific physiological traits and selective grazing pressure are crucial factors determining which diatom species dominates or co-dominate an individual bloom (Assmy et al., 2007; Assmy et al., 2013; Boyd, 2013). The chain-forming F. kerguelensis is one of the most abundant diatom species in ACC waters (e.g. Laubscher et al., 1993; Bathmann et al., 1997; Smetacek et al., 2002) and has been reported to represent up to $90 \%$ of the summer diatom populations in the AZ (Gall et al., 2001). The high relative contribution of $F$. kerguelensis throughout our record is consistent with these latter studies and suggests the presence of a large seeding population of this species before the onset of the bloom. These large initial seed stocks, together with the effective mechanical protection of its robust frustule (Hamm et al., 2003) against the heavy copepod grazing pressure of the ACC (Pollard et al., 2002; McLeod 
et al., 2010) are most likely the main factors determining the dominance of $F$. kerguelensis during the growth season. The increase in the relative abundance of the lightly silicified Pseudo-nitzschia cf. lineola and small Fragilariopsis species during the second part of the bloom (Figs. 5b and 7) is consistent with the observations of Kopczynska et al. (2001) who reported $F$. pseudonana and $P-n$. lineola dominating the diatom assemblages in the PFZ waters south of Tasmania during late summer. Assmy et al. (2007) reported large numbers of $P$ - $n$. lineola during the last stages of the fertilisation experiment EisenEx, indicating the capacity of this diatom to outcompete other taxa under iron-limiting conditions. Moreover, small Fragilariopsis and Pseudo-nitzschia species are known to produce an iron-storage protein (ferritin) that allow them to undergo more cell divisions than other open-ocean diatoms under low iron concentrations (Marchetti et al., 2009). We speculate, that due to these particular physiological traits Pseudo-nitzschia and small Fragilariopsis species may gain a competitive advantage under the environmental conditions during the last stages of the diatom bloom (i.e. low silica and iron concentrations, and enhanced PAR), enabling such species to escape grazing and/or outcompete other diatoms. However, this scenario does not account for our observations in 2002-2003, when Pseudo-nitzschia and small Fragilariopsis species exhibited higher relative contribution in the first seasonal export peak (Figs. 5b and 7). This exceptional seasonal flux peak remained unexplained and likely due to other environmental conditions not captured by our study.

\subsection{Ecological flux vectors in the PFZ}

The short and vigorous summer particle export, consistently observed during our 6 year record at the $54^{\circ} \mathrm{S}$ trap is characteristic of high latitude systems (e.g. Honjo et al., 2000; Fischer et al., 2002; Pilskaln et al., 2004) and can contribute up to $66 \%$ of the annual POC export to $800 \mathrm{~m}$ in just 2 months (e.g. 1999-2000). Therefore, these large summer pulses of POC are responsible for a major proportion of the variability in carbon sequestration from the atmosphere in the PFZ. The mechanism is primarily through the increase in the overall flux, because the fractional POC content was not observed to increase during high flux periods. For example, \% POC for the year 1999-2000 ranged between $1.2 \%$ and 3.7, and maximum relative abundances occurred at times of relatively low fluxes (Fig. 3b).

The strong positive correlation between factor 1 and POC fluxes at the $54^{\circ} \mathrm{S}$ site (Table 6) indicates an intimate association between high relative abundances of the high-export group species and pulses of POC export. As a specific example of this, during January 1999 and December 2000, when the highest contribution of the high-export group was noted (55-60\% of the total diatom flux; Fig 7), the PFZ sediment trap registered the largest POC fluxes of the record (up to $23 \mathrm{mg} \mathrm{m}^{-2} \mathrm{~d}^{-1}$; Fig. 7). Interestingly, these observations of elevated POC flux coincide with significantly lower summer SSTs than other years.

All the members of the high-export group have been previously reported as important components of both natural and iron-fertilised blooms in the Southern Ocean (Bathmann et al., 1997; Waite and Nodder, 2001; Smetacek et al., 2002; Assmy et al., 2007; Quéguiner, 2013; Grigorov et al., 2014; Rigual-Hernández et al., 2015). The increase in the relative abundance and fluxes of these species during the growth season indicates that they respond opportunistically to the enhanced light levels, most likely undergoing cycles of rapid biomass build-up followed by mass mortality and sinking in the form of aggregates (Smetacek et al., 2004; Green and Sambrotto, 2006; Assmy et al., 2013). This concept is supported by the recent findings of Closset et al. (2015) who documented an increase in the particle sinking speeds at the $54^{\circ} \mathrm{S}$ site during the summer 1999-2000 of up to at least $35 \mathrm{~m} \mathrm{~d}^{-1}$, a value that falls within the range of previous estimates for marine snow sinking rates (Turner, 2002; Trull et al., 2008; Laurenceau-Cornec et al., 2015). Moreover, other regionally relevant PFZ studies (Ebersbach et al., 2011; Grigorov et al., 2014) concluded that aggregates are the principal form of particle export during the growth season. Taken together, our data and these studies strongly suggest that aggregate formation is a widespread mechanism of the summer bloom in the open-ocean waters of the ACC.

We speculate that the massive development of high-export group diatoms during the growth season facilitates the formation of aggregates in the upper water column, which results in an increase in sinking rates and POC fluxes. Aggregates, and particularly diatom flocs, are rich in exopolymers that increase their effectiveness at scavenging particles they have collided with (Alldredge and McGillivary, 1991; Passow and De La Rocha, 2006). Therefore, it is possible that the formation of aggregates during the diatom bloom facilitated the scavenging of other particles (including phytoplankton chains and cells, biominerals and detritus), leading to the co-sedimentation of the major components of the flux (i.e. calcium carbonate, silica and organic carbon). This scavenging mechanism is consistent with previous laboratory observations made by Passow and De La Rocha (2006) and can explain the increase of the sinking rates during the growth season as well as the positive correlation between factor 1 and all bulk components of the flux (Fig. 6b, Table 6b).

Since most of the members of the high-export group are of relatively small in size and weakly silicified, it is unlikely that these species accounted for the major fraction of the BSi export during the summer bloom for most of the years. In contrast, the thick-shelled $F$. kerguelensis is a more compelling candidate to be responsible for the bulk of the BSi export, because despite the fact that its relative abundance exhibited the lowest values of the record during summer, its valve fluxes always were the highest during this season. In terms of carbonate export, the correlation between factor 1 and carbonate flux is not as strong as with the rest of the components of the 
flux but still high (Fig. 6b, Table 6b), indicating that highest relative contribution of the high-export group diatoms is also associated with high carbonate export. Although speculative, it is possible that the formation of aggregates during the diatom bloom also facilitated the scavenging of at least the fine fraction of the carbonate (mainly coccoliths; Ziveri et al., 2007; Iversen and Ploug, 2010) which would have led to the co-sedimentation of the $\mathrm{BSi}, \mathrm{POC}$ and carbonate fractions. However, other seasonal ecological influences are also likely to be involved, given that the contribution of larger carbonate particles in the form of foraminifera tests is also increased in summer (King and Howard, 2003).

The massive sedimentation of giant diatoms characteristic of the SCM shade flora (e.g. Thalassiothrix and some rhizosolenids) in autumn and winter (the so-called fall dump) has been hypothesised to contribute to a substantial fraction of the annual carbon export in the PFZ (Kemp et al., 2006; Kemp and Villareal, 2013; Quéguiner, 2013). At the $54^{\circ} \mathrm{S}$ site, the highest fluxes and relative contribution of the deep dwellers Thalassiothrix antarctica and Proboscia were recorded between the end of the productive period and winter (Fig. 5); however their contribution to the total diatom assemblage was always low $(<3.6 \%)$ and their flux pulses were not coupled with significant increases in POC export (Fig. 7). Thus, our data do not provide evidence that the sedimentation of these species was associated with a "fall dump" in the PFZ south of Tasmania. However, it has been suggested that sediment traps do not act as good samplers of large mats formed by these long diatoms (Kemp et al., 2006), and therefore their mass sedimentation during autumn and/or winter could have been missed by our sampling technique.

\subsection{Relative importance of the SAZ and PFZ to carbon export}

The depth at which the organic carbon is re-mineralised to $\mathrm{CO}_{2}$ by zooplankton and bacteria determines the timescales during which carbon is sequestered from the atmosphere (Yamanaka and Tajika, 1996; Smetacek et al., 2012). In the SAZ and the PFZ, the fraction of organic carbon recycled within the winter mixed layer $(>400 \mathrm{~m}$ in the SAZ and between 150 and $200 \mathrm{~m}$ in the PFZ; Rintoul and Bullister, 1999; Rintoul and Trull, 2001) would re-equilibrate with the atmosphere within months, whereas only the comparatively smaller portion that reaches deeper layers will remain in the ocean interior for centuries or longer timescales (Trull et al., 2001a). Thus, from the perspective of carbon sequestration, the POC fluxes measured by the traps reported in this study are probably of greater importance than those re-mineralised at middepths.

Despite the fact that total mass fluxes in the PFZ at $\sim 1 \mathrm{~km}$ were twofold larger than those of the SAZ, the annual POC export was almost identical in both regions (Fig. 8a), implying that particles sinking out of the mixed layer in the SAZ were relatively POC rich (Trull et al., 2001a; Ebersbach et al., 2011). Taking into account that gross primary production is similar in the two zones, or perhaps somewhat lower in the PFZ (Fig. 8b; Lourey and Trull, 2001; Cavagna et al., 2011; Westwood et al., 2011), our results challenge the notion that for a given similar level of production, diatomdominated ecosystems export greater amounts of carbon to the deep ocean than ecosystems dominated by smaller, nonsiliceous phytoplankton (Buesseler, 1998; Boyd and Newton, 1999; Laws et al., 2000). Trull et al. (2001) hypothesised that the similar POC export at both sites could be due to either (1) a more efficient repackaging of carbon for deep transport by the zooplankton community in the SAZ than in the PFZ or (2) to the fact that the silicate-rich particles exported in the PFZ may experience stronger loses of organic carbon at mesopelagic depths than do the carbonate-rich particles of the SAZ. Results from of the SAZ-sense programme (Bowie et al., 2011b) taken together with the data presented in this study provide key information to assess these hypotheses.

Analysis of the flux size spectra at the 47 and $54^{\circ} \mathrm{S}$ sites by Ebersbach et al. (2011) during January and February 2007 revealed that the vertical export at both stations was dominated by heavily processed particles, mainly faecal aggregates with a slight shift towards smaller particles within the PFZ due to abundant chains of diatoms sinking individually or as part of unconsolidated aggregates. Although the latter study was limited to a short observational period, the results of Ebersbach et al. (2011) suggest that zooplankton grazing had a similar impact on the control of particle export at both sites, and therefore the first hypothesis seems unlikely.

On the other hand, our data show that only a few diatom species, particularly F. kerguelensis, dominate the particle export in the silicate-rich and iron-limited waters of the PFZ and AZ. Most of these species are known to significantly increase their BSi:PON and BSi:POC ratios under iron deficiency resulting in the thickening of its already robust frustule (Takeda, 1998; Hoffmann et al., 2007). Furthermore, recent findings from the European Iron Fertilisation Experiment (EIFEX; Smetacek et al., 2012) illustrated that the cellular content of a large fraction of the F. kerguelensis stock outside and inside the patch was recycled in the surface layer, resulting in the disproportional sinking of empty frustules to the deep ocean (Assmy et al., 2013). Assmy et al. (2013) concluded that due to these particular traits, $F$. kerguelensis and other exceptionally robust diatoms, such as Thalassiosira lentiginosa and Thalassionema nitzschioides, preferentially sequester silicon relative to carbon in the ironlimited waters of the ACC. This concept is consistent with our findings in the open waters of the Australian sector south of the SAF, and would help to explain the low POC content and POC:BSi ratios of the particles registered at meso- and bathypelagic depths by our PFZ and AZ traps.

Significantly, comparisons of our results (Fig. 8a) with satellite and in situ measurements of primary production (Fig. 8b) suggest that high BSi sedimentation rates should be interpreted as a proxy for iron-limited diatom assemblages 
(Hutchins and Bruland, 1998; Takeda, 1998; Assmy et al., 2013) rather than for high primary production. This conclusion raises corresponding caution to previous studies that suggest that higher BSi fluxes in the past refer to a stronger biological carbon pump (Anderson et al., 2009; Sigman et al., 2010).

\section{Conclusions}

This study reports on the chemical (biogenic silica, carbonate and POC) and biological (diatoms) composition of material exported at $\sim 1 \mathrm{~km}$ depth at two sites representative of two major hydrological regions of the Australian sector of the Southern Ocean, the SAZ and PFZ. As a result of different algal communities, the composition and magnitude of the sinking particle fluxes was very different between sites, with higher and BSi-dominated fluxes in the PFZ versus lower and carbonate-dominated fluxes in the SAZ. Despite these differences, the POC export reaching the traps was indistinguishable between sites $\left(\sim 1 \mathrm{~g} \mathrm{~m}^{-2} \mathrm{yr}^{-1}\right)$. Seasonality and flux magnitude was more pronounced in the PFZ. The vigorous settling of biogenic particles during summer in the PFZ accounted for a large fraction of the annual POC export. These summer pulses are a major factor responsible for the variability in carbon sequestration from the atmosphere in this region. Our results suggest that the development of a group of bloom-forming diatom species during the growth season probably led to the formation of algal and/or faecal aggregates. The production and sinking of these aggregates most likely facilitated the scavenging of other particles in the water column, and thus the co-sedimentation of the all the components of the flux. Fragilariopsis kerguelensis dominated the diatom sinking assemblage at both sites and was considered the major biological vector decoupling the carbon and silicon cycles in the waters south the SAF. Comparisons of our data with in situ and satellite primary production estimates led us to conclude that high BSi accumulation rates in the sedimentary record should be interpreted as a proxy for ironlimited diatom assemblages rather than for a stronger biological pump.

\section{The Supplement related to this article is available online at doi:10.5194/bg-12-5309-2015-supplement.}

Acknowledgements. We thank Oscar Romero and an anonymous reviewer for their constructive comments that helped us to improve the manuscript. The SAZ Project sediment trap moorings have received support from many sources, including Australian Antarctic Sciences awards AAS1156 and AA2256 (T. Trull), the US National Science Foundation Office of Polar Programs (R. Francois, T. Trull, S. Honjo and S. Manganini), the Belgian Science and Policy Office (F. Dehairs), CSIRO Marine Laboratories, and the
Australian Integrated Marine Observing System (of which they are currently a component of the IMOS Southern Ocean Time Series Facility; www.imos.org.au). This work was made possible by the Australian Government's Australian Antarctic Science Grant Program (project number 4078) and Macquarie University (A. Rigual-Hernández and L. Armand). The chlorophyll $a$ and PAR data sets and chlorophyll $a$ visualisations used in this paper were produced with the Giovanni online data system, developed and maintained by the NASA GES DISC. Primary productivity estimates were made available by the Ocean Productivity website (http://www.science.oregonstate.edu/ocean.productivity/). Diana M. Davies is thanked for performing biogeochemical analyses on the trap material. Anne-Marie Ballegeer is acknowledged for her technical support in the preparation of samples and comments on an early draft of the manuscript. Thanks to Jan Lieser and John Baumgartner for their assistance in the remote sensing analysis. The authors are thankful to Jessica Wilks and Kelly Lawler for their help in the microscopy analysis and taxonomic identifications. The authors acknowledge the assistance and support of Nicole Vella and Debra Birch from the Macquarie University Microscopy Unit in the scanning electron microscopy analysis.

Edited by: E. Marañón

\section{References}

Abrantes, F.: Diatom assemblages as upwelling indicators in surface sediments off Portugal, Mar. Geol., 85, 15-39, 1988.

Acker, J. G. and Leptoukh, G.: Online Analysis Enhances Use of NASA Earth Science Data, Eos, Transactions. AGU, 88, 14-17, 2007.

Alldredge, A. L. and McGillivary, P.: The attachment probabilities of marine snow and their implications for particle coagulation in the ocean, Deep-Sea Res. Pt. I, 38, 431-443, 1991.

Alvain, S., Moulin, C., Dandonneau, Y., and Bréon, F. M.: Remote sensing of phytoplankton groups in case 1 waters from global SeaWiFS imagery, Deep-Sea Res. Pt. I, 52, 1989-2004, 2005.

Alvain, S., Moulin, C., Dandonneau, Y., and Loisel, H.: Seasonal distribution and succession of dominant phytoplankton groups in the global ocean: A satellite view, Global Biogeochem. Cy., 22, GB3001, doi:10.1029/2007GB003154, 2008.

Alvain, S., Le Quéré, C., Bopp, L., Racault, M.-F., Beaugrand, G., Dessailly, D., and Buitenhuis, E. T.: Rapid climatic driven shifts of diatoms at high latitudes, Remote Sens. Environ., 132, 195201, 2013.

Anderson, R. F., Chase, Z., Fleisher, M. Q., and Sachs, J.: The Southern Ocean's biological pump during the Last Glacial Maximum, Deep-Sea Res. Pt. II, 49, 1909-1938, 2002.

Anderson, R. F., Ali, S., Bradtmiller, L. I., Nielsen, S. H. H., Fleisher, M. Q., Anderson, B. E., and Burckle, L. H.: WindDriven Upwelling in the Southern Ocean and the Deglacial Rise in Atmospheric $\mathrm{CO}_{2}$, Science, 323, 1443-1448, 2009.

Armand, L. K., Crosta, X., Romero, O., and Pichon, J.-J.: The biogeography of major diatom taxa in Southern Ocean sediments: 1. Sea ice related species, Palaeogeogr. Palaeoecol., 223, 93-126, 2005.

Armand, L. K. A.: The use of diatom transfer functions in estimating sea-surface temperature and sea-ice in cores from the south- 
east Indian Ocean, PhD, Australian National University, Canberra, Australia, 932 pp., 1997.

Arrigo, K. R. and van Dijken, G. L.: Phytoplankton dynamics within 37 Antarctic coastal polynya systems, J. Geophys. Res.-Oceans, 108, 3271, doi:10.1029/2002JC001739, 2003.

Arrigo, K. R., Worthen, D., Schnell, A., and Lizotte, M. P.: Primary production in Southern Ocean waters, J. Geophys. Res.-Oceans, 103, 15587-15600, 1998.

Arrigo, K. R., van Dijken, G. L., and Bushinsky, S.: Primary production in the Southern Ocean, 1997-2006, J. Geophys. Res.Oceans, 113, C08004, doi:10.1029/2007JC004551, 2008.

Assmy, P., Henjes, J., Klaas, C., and Smetacek, V.: Mechanisms determining species dominance in a phytoplankton bloom induced by the iron fertilization experiment EisenEx in the Southern Ocean, Deep-Sea Res. Pt. I, 54, 340-362, 2007.

Assmy, P., Smetacek, V., Montresor, M., Klaas, C., Henjes, J., Strass, V. H., Arrieta, J. M., Bathmann, U., Berg, G. M., Breitbarth, E., Cisewski, B., Friedrichs, L., Fuchs, N., Herndl, G. J., Jansen, S., Krägefsky, S., Latasa, M., Peeken, I., Röttgers, R., Scharek, R., Schüller, S. E., Steigenberger, S., Webb, A., and Wolf-Gladrow, D.: Thick-shelled, grazer-protected diatoms decouple ocean carbon and silicon cycles in the iron-limited Antarctic Circumpolar Current, P. Natl. Acad. Sci., 110, 2063320638, 2013.

Baker, E. T., Milburn, H. B., and Tennant, D. A.: Field assessment of sediment trap efficiency under varying flow conditions, J. Mar. Res., 46, 573-592, 1988.

Balch, W. M.: Re-evaluation of the physiological ecology of coccolithophores, n: Coccolithophores, From Molecular Processes to Global Impact., edited by: Thierstein, H. R. and Young, J. R., Springer-Verlag, Berlin, 165-190, 2004.

Bárcena, M. A. and Abrantes, F.: Evidence of a high-productivity area off the coast of Málaga from studies of diatoms in surface sediments, Mar. Micropaleontol., 35, 91-103, 1998.

Bathmann, U. V., Scharek, R., Klaas, C., Dubischar, C. D., and Smetacek, V.: Spring development of phytoplankton biomass and composition in major water masses of the Atlantic sector of the Southern Ocean, Deep-Sea Res. Pt. II, 44, 51-67, 1997.

Behrenfeld, M. J. and Falkowski, P. G.: Photosynthetic rates derived from satellite-based chlorophyll concentration, Limnol. Oceanogr., 42, 1-20, 1997.

Behrenfeld, M. J., Boss, E., Siegel, D. A., and Shea, D. M.: Carbon-based ocean productivity and phytoplankton physiology from space, Global Biogeochem. Cy., 19, GB1006, doi:10.1029/2004GB002299, 2005.

Bishop, J. K. B. and Rossow, W. B.: Spatial and temporal variability of global surface solar irradiance, J. Geophys. Res.-Oceans, 96, 16839-16858, 1991.

Blain, S., Tréguer, P., Belviso, S., Bucciarelli, E., Denis, M., Desabre, S., Fiala, M., Martin Jézéquel, V., Le Fèvre, J., Mayzaud, P., Marty, J.-C., and Razouls, S.: A biogeochemical study of the island mass effect in the context of the iron hypothesis: Kerguelen Islands, Southern Ocean, Deep-Sea Res. Pt. I, 48, 163-187, 2001.

Bowie, A. R., Lannuzel, D., Remenyi, T. A., Wagener, T., Lam, P. J., Boyd, P. W., Guieu, C., Townsend, A. T., and Trull, T. W.: Biogeochemical iron budgets of the Southern Ocean south of Australia: Decoupling of iron and nutrient cycles in the subantarctic zone by the summertime supply, Global Biogeochem. Cy., 23, GB4034, doi:10.1029/2009GB003500, 2009.

Bowie, A. R., Brian Griffiths, F., Dehairs, F., and Trull, T.: Oceanography of the subantarctic and Polar Frontal Zones south of Australia during summer: Setting for the SAZ-Sense study, Deep-Sea Res. Pt. II, 58, 2059-2070, 2011a.

Bowie, A. R., Trull, T. W., and Dehairs, F.: Estimating the sensitivity of the subantarctic zone to environmental change: The SAZSense project, Deep-Sea Res. Pt. II, 58, 2051-2058, 2011 b.

Boyd, P. W.: Environmental factors controlling phytoplankton processes in the Southern Ocean, J. Phycol., 38, 844-861, 2002.

Boyd, P. W.: Diatom traits regulate Southern Ocean silica leakage, P. Natl. Acad. Sci., 110, 20358-20359, 2013.

Boyd, P. W. and Newton, P. P.: Does planktonic community structure determine downward particulate organic carbon flux in different oceanic provinces?, Deep-Sea Res. Pt. I, 46, 63-91, 1999.

Boyd, P. W. and Trull, T. W.: Understanding the export of biogenic particles in oceanic waters: Is there consensus?, Progr. Oceanogr., 72, 276-312, 2007.

Boyd, P. W., LaRoche, J., Gall, M. P., Frew, R., and McKay, R. M. L.: Role of iron, light, and silicate in controlling algal biomass in subantarctic waters SE of New Zealand, J. Geophys. Res.Oceans, 104, 13395-13408, 1999.

Boyd, P. W., Crossley, A. C., DiTullio, G. R., Griffiths, F. B., Hutchins, D. A., Queguiner, B., Sedwick, P. N., and Trull, T. W.: Control of phytoplankton growth by iron supply and irradiance in the subantarctic Southern Ocean: Experimental results from the SAZ Project, J. Geophys. Res.-Oceans, 106, 31573-31583, 2001.

Boyd, P. W., Jickells, T., Law, C. S., Blain, S., Boyle, E. A., Buesseler, K. O., Coale, K. H., Cullen, J. J., de Baar, H. J. W., Follows, M., Harvey, M., Lancelot, C., Levasseur, M., Owens, N. P. J., Pollard, R., Rivkin, R. B., Sarmiento, J., Schoemann, V., Smetacek, V., Takeda, S., Tsuda, A., Turner, S., and Watson, A. J.: Mesoscale Iron Enrichment Experiments 1993-2005: Synthesis and Future Directions, Science, 315, 612-617, 2007.

Boyd, P. W., Strzepek, R., Fu, F., and Hutchins, D. A.: Environmental control of open-ocean phytoplankton groups: Now and in the future, Limnol. Oceanogr., 55, 1353-1376, 2010.

Bracher, A., Kroon, B., and Lucas, M.: Primary production, physiological state and composition of phytoplankton in the Atlantic sector ot the Southern Ocean, Mar. Ecol.-Prog. Ser., 190, 1-16, 1999.

Bray, S., Trull, T. W., and Manganini, S.: SAZ Project Moored Sediment Traps: Results of the 1997-1998 Deployments, Antarctic Cooperative Research Centre, Hobart, Tasmania, Australia, 128 pp., 2000.

Brzezinski, M. A., Nelson, D. M., Franck, V. M., and Sigmon, D. E.: Silicon dynamics within an intense open-ocean diatom bloom in the Pacific sector of the Southern Ocean, Deep-Sea Res. Pt. II, 48, 3997-4018, 2001.

Brzezinski, M. A., Pride, C. J., Franck, V. M., Sigman, D. M., Sarmiento, J. L., Matsumoto, K., Gruber, N., Rau, G. H., and Coale, K. H.: A switch from $\mathrm{Si}(\mathrm{OH}) 4$ to NO3- depletion in the glacial Southern Ocean, Geophys. Res. Lett., 29, 5-1-5-4, 2002.

Buesseler, K. O.: The decoupling of production and particulate export in the surface ocean, Global Biogeochem. Cy., 12, 297-310, 1998. 
Buesseler, K. O., Ball, L., Andrews, J., Cochran, J. K., Hirschberg, D. J., Bacon, M. P., Fleer, A., and Brzezinski, M.: Upper ocean export of particulate organic carbon and biogenic silica in the Southern Ocean along $170^{\circ}$ W, Deep-Sea Res. Pt. II, 48, 42754297, 2001.

Buesseler, K. O., Antia, A. N., Chen, M., Fowler, S. W., Gardner, W. D., Gustafsson, O., Harada, K., Michaels, A. F., der Loeff, M. R. v., and Sarin, M.: An assessment of the use of sediment traps for estimating upper ocean particle fuxes, J. Mar. Res., 65, 345-416, 2007.

Burckle, L. H. and Cirilli, J.: Origin of Diatom Ooze Belt in the Southern Ocean: Implications for Late Quaternary Paleoceanography, Micropaleontology, 33, 82-86, 1987.

Burd, A. B. and Jackson, G. A.: Particle aggregation, Annu. Rev. Mar. Sci., 1, 65-90, 2009.

Cavagna, A.-J., Elskens, M., Griffiths, F. B., Fripiat, F., Jacquet, S. H. M., Westwood, K. J., and Dehairs, F.: Contrasting regimes of production and potential for carbon export in the Sub-Antarctic and Polar Frontal Zones south of Tasmania, Deep-Sea Res. Pt. II, 58, 2235-2247, 2011.

Closset, I., Cardinal, D., Bray, S. G., Thil, F., Djouraev, I., RigualHernández, A. S., and Trull, T. W.: Seasonal variations, origin and fate of settling diatoms in the Southern Ocean tracked by silicon isotope records in deep sediment traps, Global Biogeochem. Cy., doi:10.1002/2015GB005180, 2015.

Crosta, X., Pichon, J.-J., and Labracherie, M.: Distribution of Chaetoceros resting spores in modern peri-Antarctic sediments, Mar. Micropaleontol., 29, 283-299, 1997.

Crosta, X., Romero, O., Armand, L. K., and Pichon, J.-J.: The biogeography of major diatom taxa in Southern Ocean sediments: 2. Open ocean related species, Palaeogeogr. Palaeoecol., 223, 6692, 2005.

De La Rocha, C.: The biological pump, in: Geochemistry of Earth Surface Systems: A derivative of the Treatise on Geochemistry, edited by: Holland, H. D. and Turekian, K. K.), Academic Press, 425 pp., 2010.

de Salas, M. F., Eriksen, R., Davidson, A. T., and Wright, S. W.: Protistan communities in the Australian sector of the Sub-Antarctic Zone during SAZ-Sense, Deep-Sea Res. Pt. II, 58, 2135-2149, 2011.

Deacon, G. E. R.: Physical and biological zonation in the Southern Ocean, Deep-Sea Res. Pt. I, 29, 1-15, 1982.

DeMaster, D. J.: The accumulation and cycling of biogenic silica in the Southern Ocean: revisiting the marine silica budget, DeepSea Res. Pt. II, 49, 3155-3167, 2002.

DeMaster, D. J.: The supply and accumulation of silica in the marine environment, Geochim. Cosmochim. Ac., 45, 1715-1732, 1981.

Downes, S. M., Bindoff, N. L., and Rintoul, S. R.: Impacts of Climate Change on the Subduction of Mode and Intermediate Water Masses in the Southern Ocean, J. Climate, 22, 3289-3302, 2009.

Ebersbach, F., Trull, T. W., Davies, D. M., and Bray, S. G.: Controls on mesopelagic particle fluxes in the Sub-Antarctic and Polar Frontal Zones in the Southern Ocean south of Australia in summer - Perspectives from free-drifting sediment traps, DeepSea Res. Pt. II, 58, 2260-2276, 2011.

Esper, O., Gersonde, R., and Kadagies, N.: Diatom distribution in southeastern Pacific surface sediments and their relationship to modern environmental variables, Palaeogeogr. Palaeoecol., 287, 1-27, 2010.

Falkowski, P. G., Barber, R. T., and Smetacek, V.: Biogeochemical Controls and Feedbacks on Ocean Primary Production, Science, 281, 200-206, 1998.

Fetterer, F., Knowles, K., Meier, W., and Savoie, M.: Sea Ice Index, Sea Ice Extent, Center, Boulder, Colorado USA, 2002, updated 2009.

Findlay, C. S. and Giraudeau, J.: Extant calcareous nannoplankton in the Australian Sector of the Southern Ocean (austral summers 1994 and 1995), Mar. Micropaleontol., 40, 417-439, 2000.

Fischer, G., Gersonde, R., and Wefer, G.: Organic carbon, biogenic silica and diatom fluxes in the marginal winter sea-ice zone and in the Polar Front Region: interannual variations and differences in composition, Deep-Sea Res. Pt. II, 49, 1721-1745, 2002.

Fitzwater, S. E., Johnson, K. S., Gordon, R. M., Coale, K. H., and Smith Jr, W. O.: Trace metal concentrations in the Ross Sea and their relationship with nutrients and phytoplankton growth, Deep-Sea Res. Pt. II, 47, 3159-3179, 2000.

Gall, M. P., Boyd, P. W., Hall, J., Safi, K. A., and Chang, H.: Phytoplankton processes. Part 1: Community structure during the Southern Ocean Iron RElease Experiment (SOIREE), Deep-Sea Res. Pt. II, 48, 2551-2570, 2001.

Gersonde, R. and Zielinski, U.: The reconstruction of late Quaternary Antarctic sea-ice distribution - the use of diatoms as a proxy for sea-ice, Palaeogeogr. Palaeoecol., 162, 263-286, 2000.

Green, S. E. and Sambrotto, R. N.: Plankton community structure and export of C, N, P and Si in the Antarctic Circumpolar Current, Deep-Sea Res. Pt. II, 53, 620-643, 2006.

Gregg, W. W. and Rousseaux, C. S.: Decadal trends in global pelagic ocean chlorophyll: A new assessment integrating multiple satellites, in situ data, and models, J. Geophys. Res.-Oceans, 119, 5921-5933, 2014.

Grigorov, I., Rigual-Hernandez, A. S., Honjo, S., Kemp, A. E. S., and Armand, L. K.: Settling fluxes of diatoms to the interior of the antarctic circumpolar current along $170^{\circ} \mathrm{W}$, Deep-Sea Res. Pt. I, 93, 1-13, 2014.

Grossart, H., Kiørboe, T., Tang, K., Allgaier, M., Yam, E., and Ploug, H.: Interactions between marine snow and heterotrophic bacteria: aggregate formation and microbial dynamics, Aquat. Microb. Ecol., 42, 19-26, 2006.

Gust, G., Byrne, R. H., Bernstein, R. E., Betzer, P. R., and Bowles, W.: Particles fluxes and moving fluids: experience from synchronous trap collection in the Sargassso sea, Deep-Sea Res. Pt I, 39, 1071-1083, 1992.

Hamilton, K. M.: Evaluating the consistency of satellite and deep sediment trap carbon export data in the Southern Ocean, 2006 , Honours thesis, Institute of Antarctic and Southern Ocean Studies, University of Tasmania, Hobart, Tasmania, 151 pp., 2006.

Hamm, C. E., Merkel, R., Springer, O., Jurkojc, P., Maier, C., Prechtel, K., and Smetacek, V.: Architecture and material properties of diatom shells provide effective mechanical protection, Nature, 421, 841-843, 2003.

Hart, T. J.: On the phytoplankton of the south-west Atlantic and the Bellingshausen Sea, 1929-31, University Press, 1-268, 1934.

Hasle, G. R.: An analysis of the phytoplankton of the Pacific Southern Ocean: abundance, composition, and distribution during the Brategg Expedition, 1947-1948, Universitetsforlaget, Oslo, 1168, 1969. 
Hasle, G. R. and Syvertsen, E. E.: Marine diatoms, Identifying marine phytoplankton. Academic Press, San Diego, CA, 1997, 5385, 1997.

Herraiz-Borreguero, L. and Rintoul, S. R.: Subantarctic Mode Water variability influenced by mesoscale eddies south of Tasmania, J. Geophys. Res.-Oceans, 115, C04004, doi:10.1029/2008JC005146, 2010.

Herraiz-Borreguero, L. and Rintoul, S. R.: Regional circulation and its impact on upper ocean variability south of Tasmania, DeepSea Res. Pt. II, 58, 2071-2081, 2011.

Hoffmann, L. J., Peeken, I., and Lochte, K.: Effects of iron on the elemental stoichiometry during EIFEX and in the diatoms Fragilariopsis kerguelensis and Chaetoceros dichaeta, Biogeosciences, 4, 569-579, doi:10.5194/bg-4-569-2007, 2007.

Honjo, S.: Particle export and the biological pump in the Southern Ocean, Antarct. Sci., 16, 501-516, 2004.

Honjo, S., Francois, R., Manganini, S., Dymond, J., and Collier, R.: Particle fluxes to the interior of the Southern Ocean in the Western Pacific sector along $170^{\circ}$ W, Deep-Sea Res. Pt. II, 47, 3521-3548, 2000.

Honjo, S., Manganini, S. J., Krishfield, R. A., and Francois, R.: Particulate organic carbon fluxes to the ocean interior and factors controlling the biological pump: A synthesis of global sediment trap programs since 1983, Progr. Oceanogr., 76, 217-285, 2008.

Howard, W. R., Roberts, D., Moy, A. D., Lindsay, M. C. M., Hopcroft, R. R., Trull, T. W., and Bray, S. G.: Distribution, abundance and seasonal flux of pteropods in the Sub-Antarctic Zone, Deep-Sea Res. Pt. II, 58, 2293-2300, 2011.

Hutchins, D. A. and Bruland, K. W.: Iron-limited diatom growth and Si:N uptake ratios in a coastal upwelling regime, Nature, 393, 561-564, 1998.

Iversen, M. H. and Ploug, H.: Ballast minerals and the sinking carbon flux in the ocean: carbon-specific respiration rates and sinking velocity of marine snow aggregates, Biogeosciences, 7 , 2613-2624, doi:10.5194/bg-7-2613-2010, 2010.

Johnson, K. S., Gordon, R. M., and Coale, K. H.: What controls dissolved iron concentrations in the world ocean?, Mar. Chem., 57, 137-161, 1997.

Kemp, A. E. S. and Villareal, T. A.: High diatom production and export in stratified waters - A potential negative feedback to global warming, Progr. Oceanogr., 119, 4-23, 2013.

Kemp, A. E. S., Pearce, R. B., Grigorov, I., Rance, J., Lange, C. B., Quilty, P., and Salter, I.: Production of giant marine diatoms and their export at oceanic frontal zones: Implications for $\mathrm{Si}$ and C flux from stratified oceans, Global Biogeochem. Cy., 20, doi:10.1029/2006GB002698, 2006.

King, A. L. and Howard, W. R.: Planktonic foraminiferal flux seasonality in Subantarctic sediment traps: A test for paleoclimate reconstructions, Paleoceanography, 18, doi:10.1029/2002PA000839, 2003.

King, A. L. and Howard, W. R.: $\delta 180$ seasonality of planktonic foraminifera from Southern Ocean sediment traps: Latitudinal gradients and implications for paleoclimate reconstructions, Mar. Micropaleontol., 56, 1-24, 2005.

Kohfeld, K. E., Quéré, C. L., Harrison, S. P., and Anderson, R. F.: Role of Marine Biology in Glacial-Interglacial $\mathrm{CO}_{2}$ Cycles, Science, 308, 74-78, 2005.
Kopczynska, E. E., Weber, L. H., and El-Sayed, S. Z.: Phytoplankton species composition and abundance in the Indian sector of the Antarctic Ocean, Polar Biol., 6, 161-169, 1986.

Kopczynska, E. E., Dehairs, F., Elskens, M., and Wright, S.: Phytoplankton and microzooplankton variability between the Subtropical and Polar Fronts south of Australia: Thriving under regenerative and new production in late summer, J. Geophys. Res.Oceans, 106, 31597-31609, 2001.

Kozlova, A.: Diatom algae of the Indian and Pacific sectors of Antarctica, Academy of Sciences of the USSR Institute of Oceanology, Moscow, 1966. 1-191, 1966.

Lampitt, R. S. and Antia, A. N.: Particle flux in deep seas: regional characteristics and temporal variability, Deep-Sea Res. Pt. I, 44, 1377-1403, 1997.

Lampitt, R. S., Salter, I., and Johns, D.: Radiolaria: Major exporters of organic carbon to the deep ocean, Global Biogeochem. Cy., 23, GB1010, doi:10.1029/2008GB003221, 2009.

Lannuzel, D., Bowie, A. R., Remenyi, T., Lam, P., Townsend, A., Ibisanmi, E., Butler, E., Wagener, T., and Schoemann, V.: Distributions of dissolved and particulate iron in the sub-Antarctic and Polar Frontal Southern Ocean (Australian sector), Deep-Sea Res. Pt. II, 58, 2094-2112, 2011.

Laubscher, R. K., Perissinotto, R., and McQuaid, C. D.: Phytoplankton production and biomass at frontal zones in the Atlantic sector of the Southern Ocean, Polar Biol., 13, 471-481, 1993.

Laurenceau-Cornec, E. C., Trull, T. W., Davies, D. M., Bray, S. G., Doran, J., Planchon, F., Carlotti, F., Jouandet, M.-P., Cavagna, A.-J., Waite, A. M., and Blain, S.: The relative importance of phytoplankton aggregates and zooplankton fecal pellets to carbon export: insights from free-drifting sediment trap deployments in naturally iron-fertilised waters near the Kerguelen Plateau, Biogeosciences, 12, 1007-1027, doi:10.5194/bg-121007-2015, 2015.

Laws, E. A., Falkowski, P. G., Smith, W. O., Ducklow, H., and McCarthy, J. J.: Temperature effects on export production in the open ocean, Global Biogeochem. Cy., 14, 1231-1246, 2000.

Ledford-Hoffman, P. A., Demaster, D. J., and Nittrouer, C. A.: Biogenic-silica accumulation in the Ross Sea and the importance of Antarctic continental-shelf deposits in the marine silica budget, Geochim. Cosmochim. Ac., 50, 2099-2110, 1986.

Leventer, A.: Sediment trap diatom assemblages from the northern Antarctic Peninsula region, Deep-Sea Res. Pt. I, 38, 1127-1143, 1991.

Leventer, A. and Dunbar, R. B.: Factors influencing the distribution of diatoms and other algae in the Ross Sea, J. Geophys. Res.Oceans, 101, 18489-18500, 1996.

Lourey, M. J. and Trull, T. W.: Seasonal nutrient depletion and carbon export in the Subantarctic and Polar Frontal zones of the Southern Ocean south of Australia, J. Geophys. Res.-Oceans, 106, 31463-31487, 2001.

Marchetti, A., Parker, M. S., Moccia, L. P., Lin, E. O., Arrieta, A. L., Ribalet, F., Murphy, M. E. P., Maldonado, M. T., and Armbrust, E. V.: Ferritin is used for iron storage in bloom-forming marine pennate diatoms, Nature, 457, 467-470, 2009.

Margalef, R.: Life-forms of phytoplankton as survival alternatives in an unstable environment, Oceanologica Acta, 1, 493-509, 1978.

Martin, J. H.: Glacial-interglacial $\mathrm{CO}_{2}$ change: The Iron Hypothesis, Paleoceanography, 5, 1-13, 1990. 
Matsumoto, K., Sarmiento, J. L., and Brzezinski, M. A.: Silicic acid leakage from the Southern Ocean: A possible explanation for glacial atmospheric $p \mathrm{CO}_{2}$, Global Biogeochem. Cy., 16, 5-15-23, 2002.

McCartney, M. S.: Subantarctic Mode Water. In: A Voyage of Discovery, Angel, edited by: Angel, M. V., Pergamon, New York, 103-119, 1977.

McLeod, D. J., Hosie, G. W., Kitchener, J. A., Takahashi, K. T., and Hunt, B. P. V.: Zooplankton Atlas of the Southern Ocean: The SCAR SO-CPR Survey (1991-2008), Polar Sci., 4, 353385,2010

Mengelt, C., Abbott, M. R., Barth, J. A., Letelier, R. M., Measures, C. I., and Vink, S.: Phytoplankton pigment distribution in relation to silicic acid, iron and the physical structure across the Antarctic Polar Front, $170^{\circ} \mathrm{W}$, during austral summer, Deep-Sea Res. Pt. II, 48, 4081-4100, 2001.

Mongin, M., Matear, R., and Chamberlain, M.: Simulation of chlorophyll and iron supplies in the Sub Antarctic Zone South of Australia, Deep-Sea Res. Pt. II, 58, 2126-2134, 2011.

Moore, J. K. and Abbott, M. R.: Phytoplankton chlorophyll distributions and primary production in the Southern Ocean, J. Geophys. Res.-Oceans, 105, 28709-28722, 2000.

Moore, J. K., Abbott, M. R., Richman, J. G., Smith, W. O., Cowles, T. J., Coale, K. H., Gardner, W. D., and Barber, R. T.: SeaWiFS satellite ocean color data from the Southern Ocean, Geophys. Res. Lett., 26, 1465-1468, 1999.

Nishida, S.: Nannoplankton flora in the Southern Ocean, with special reference to siliceous varieties, Memoirs of National Institute of Polar Research, Special issue, 40, 56-68, 1986.

Odate, T. and Fukuchi, M.: Distribution and community structure of picophytoplankton in the Southern Ocean during the late austral summer of 1992, 86-100, 1995.

Orsi, A. H., Whitworth Iii, T., and Nowlin Jr, W. D.: On the meridional extent and fronts of the Antarctic Circumpolar Current, Deep-Sea Res. Pt. I, 42, 641-673, 1995.

Park, J., Oh, I.-S., Kim, H.-C., and Yoo, S.: Variability of SeaWiFs chlorophyll-a in the southwest Atlantic sector of the Southern Ocean: Strong topographic effects and weak seasonality, DeepSea Res. Pt. I, 57, 604-620, 2010.

Parslow, J. S., Boyd, P. W., Rintoul, S. R., and Griffiths, F. B.: A persistent subsurface chlorophyll maximum in the Interpolar Frontal Zone south of Australia: Seasonal progression and implications for phytoplankton-light-nutrient interactions, J. Geophys. Res.Oceans, 106, 31543-31557, 2001.

Passow, U.: Transparent exopolymer particles (TEP) in aquatic environments, Progr. Oceanogr., 55, 287-333, 2002.

Passow, U. and De La Rocha, C. L.: Accumulation of mineral ballast on organic aggregates, Global Biogeochem. Cy., 20, GB1013, doi:10.1029/2005GB002579, 2006.

Pilskaln, C. H., Manganini, S. J., Trull, T. W., Armand, L., Howard, W., Asper, V. L., and Massom, R.: Geochemical particle fluxes in the Southern Indian Ocean seasonal ice zone: Prydz Bay region, East Antarctica, Deep-Sea Res. Pt. I, 51, 307-332, 2004.

Pollard, R., Tréguer, P., and Read, J.: Quantifying nutrient supply to the Southern Ocean, J. Geophys. Res.-Oceans, 111, C05011, doi:10.1029/2005JC003076, 2006.

Pollard, R. T., Bathmann, U., Dubischar, C., Read, J. F., and Lucas, M.: Zooplankton distribution and behaviour in the South- ern Ocean from surveys with a towed Optical Plankton Counter, Deep-Sea Res. Pt. II, 49, 3889-3915, 2002.

Popp, B. N., Trull, T., Kenig, F., Wakeham, S. G., Rust, T. M., Tilbrook, B., Griffiths, B., Wright, S. W., Marchant, H. J., Bidigare, R. R., and Laws, E. A.: Controls on the carbon isotopic composition of southern ocean phytoplankton, Global Biogeochem. Cy., 13, 827-843, 1999.

Quéguiner, B.: Biogenic silica production in the Australian sector of the Subantarctic Zone of the Southern Ocean in late summer 1998, J. Geophys. Res.-Oceans, 106, 31627-31636, 2001.

Quéguiner, B.: Iron fertilization and the structure of planktonic communities in high nutrient regions of the Southern Ocean, Deep-Sea Res. Pt. II, 90, 43-54, 2013.

Raitsos, D. E., Lavender, S. J., Maravelias, C. D., Haralabous, J., Richardson, A. J., and Reid, P. C.: Identifying four phytoplankton functional types from space: An ecological approach, Limnol. Oceanogr., 53, 605-613, 2008.

Rembauville, M., Blain, S., Armand, L., Quéguiner, B., and Salter, I.: Export fluxes in a naturally iron-fertilized area of the Southern Ocean - Part 2: Importance of diatom resting spores and faecal pellets for export, Biogeosciences, 12, 3171-3195, doi:10.5194/bg-12-3171-2015, 2015.

Reynolds, R. W., Rayner, N. A., Smith, T. M., Stokes, D. C., and Wang, W.: An improved in situ and satellite SST analysis for climate, J. Climate, 15, 1609-1625, 2002.

Ridgway, K. R. and Dunn, J. R.: Observational evidence for a Southern Hemisphere oceanic supergyre, Geophys. Res. Lett., 34, L13612, doi:10.1029/2007GL030392, 2007.

Rigual-Hernández, A. S., Bárcena, M. A., Sierro, F. J., Flores, J. A., Hernández-Almeida, I., Sanchez-Vidal, A., Palanques, A., and Heussner, S.: Seasonal to interannual variability and geographic distribution of the silicoflagellate fluxes in the Western Mediterranean, Mar. Micropaleontol., 77, 46-57, 2010.

Rigual-Hernández, A. S., Sierro, F. J., Bárcena, M. A., Flores, J. A., and Heussner, S.: Seasonal and interannual changes of planktic foraminiferal fluxes in the Gulf of Lions (NW Mediterranean) and their implications for paleoceanographic studies: Two 12year sediment trap records, Deep-Sea Res. Pt. I, 66, 26-40, 2012.

Rigual-Hernández, A. S., Bárcena, M. A., Jordan, R. W., Sierro, F. J., Flores, J. A., Meier, K. J. S., Beaufort, L., and Heussner, S.: Diatom fluxes in the NW Mediterranean: evidence from a 12year sediment trap record and surficial sediments, J. Plankton Res., 35, 1109-1125, 2013.

Rigual-Hernández, A. S., Trull, T. W., Bray, S. G., Closset, I., and Armand, L. K.: Seasonal dynamics in diatom and particulate export fluxes to the deep sea in the Australian sector of the southern Antarctic Zone, J. Mar. Sys., 142, 62-74, 2015.

Rintoul, S. R. and Bullister, J. L.: A late winter hydrographic section from Tasmania to Antarctica, Deep-Sea Res. Pt. I, 46, 1417 1454, 1999.

Rintoul, S. R. and Trull, T. W.: Seasonal evolution of the mixed layer in the Subantarctic zone south of Australia, J. Geophys. Res.-Oceans, 106, 31447-31462, 2001.

Romero, O. and Armand, L.: Marine diatoms as indicators of modern changes in oceanographic conditions, in: The Diatoms: Applications for the Environmental and Earth Sciences, edited by: Smol, J. P. and Stoermer, E. F., 373-400, 2010.

Romero, O., Lange, C. B., Fischer, G., Treppke, U. F., and Wefer, G.: Variability in export production documented by downward 
fl uxes and species composition of marine planktonic diatoms: observations from the tropical and equatorial Atlantic, in: The Use of Proxies in Paleoceanography - Examples from the South Atlantic, edited by: Fischer, G. and Wefer, G., Springer-Verlag Berlin Heidelberg, 365-392, 1999.

Romero, O., Boeckel, B., Donner, B., Lavik, G., Fischer, G., and Wefer, G.: Seasonal productivity dynamics in the pelagic central Benguela System inferred from the flux of carbonate and silicate organisms, J. Mar. Sys., 37, 259-278, 2002.

Romero, O. E., Fischer, G., Lange, C. B., and Wefer, G.: Siliceous phytoplankton of the western equatorial Atlantic: sediment traps and surface sediments, Deep-Sea Res. Pt. II, 47, 1939-1959, 2000.

Romero, O. E., Armand, L. K., Crosta, X., and Pichon, J. J.: The biogeography of major diatom taxa in Southern Ocean surface sediments: 3. Tropical/Subtropical species, Palaeogeogr. Palaeoecol., 223, 4-9-65, 2005.

Romero, O. E., Rixen, T., and Herunadi, B.: Effects of hydrographic and climatic forcing on diatom production and export in the tropical southeastern Indian Ocean, Mar. Ecol.-Prog. Ser., 384, 6982,2009 a.

Romero, O. E., Thunell, R. C., Astor, Y., and Varela, R. A.: Seasonal and interannual dynamics in diatom production in the Cariaco Basin, Venezuela, Deep-Sea Res. Pt. I, 56, 571-581, 2009b.

Rousseaux, C. S. and Gregg, W. W.: Climate variability and phytoplankton composition in the Pacific Ocean, J. Geophys. Res.Oceans, 117, C10006, doi:10.1029/2012JC008083, 2012.

Sackett, O., Armand, L., Beardall, J., Hill, R., Doblin, M., Connelly, C., Howes, J., Stuart, B., Ralph, P., and Heraud, P.: Taxonspecific responses of Southern Ocean diatoms to $\mathrm{Fe}$ enrichment revealed by synchrotron radiation FTIR microspectroscopy, Biogeosciences, 11, 5795-5808, doi:10.5194/bg-11-5795-2014, 2014.

Sallée, J.-B., Wienders, N., Speer, K., and Morrow, R.: Formation of subantarctic mode water in the southeastern Indian Ocean, Ocean Dynamics, 56, 525-542, 2006.

Salter, I., Kemp, A. E. S., Moore, C. M., Lampitt, R. S., Wolff, G. A., and Holtvoeth, J.: Diatom resting spore ecology drives enhanced carbon export from a naturally iron-fertilized bloom in the Southern Ocean, Global Biogeochem. Cy., 26, GB1014, doi:10.1029/2010GB003977 2012.

Sancetta, C. and Calvert, S. E.: The annual cycle of sedimentation in Saanich inlet, British Columbia: implications for the interpretation of diatom fossil assemblages, Deep-Sea Res. Pt. I, 35, 7190, 1988.

Sarmiento, J. L., Gruber, N., Brzezinski, M. A., and Dunne, J. P.: High-latitude controls of thermocline nutrients and low latitude biological productivity, Nature, 427, 56-60, 2004.

Scott, F. J. and Marchant, H. J. (Eds.): Antarctic marine protists, Canberra, Australian Antarctic Division, Hobart, 563 pp., 2005.

Sedwick, P. N., Edwards, P. R., Mackey, D. J., Griffiths, F. B., and Parslow, J. S.: Iron and manganese in surface waters of the Australian subantarctic region, Deep-Sea Res. Pt. I, 44, 1239-1253, 1997.

Sedwick, P. N., DiTullio, G. R., and Mackey, D. J.: Iron and manganese in the Ross Sea, Antarctica: Seasonal iron limitation in Antarctic shelf waters, J. Geophys. Res.-Oceans, 105, 1132111336, 2000.
Sedwick, P. N., Bowie, A. R., and Trull, T. W.: Dissolved iron in the Australian sector of the Southern Ocean (CLIVAR SR3 section): Meridional and seasonal trends, Deep-Sea Res. Pt. I, 55, 911925, 2008.

Selph, K. E., Landry, M. R., Allen, C. B., Calbet, A., Christensen, S., and Bidigare, R. R.: Microbial community composition and growth dynamics in the Antarctic Polar Front and seasonal ice zone during late spring 1997, Deep-Sea Res. Pt. II, 48, 40594080, 2001.

Shadwick, E. H., Trull, T. W., Tilbrook, B., Sutton, A. J., Schulz, E., and Sabine, C. L.: Seasonality of biological and physical controls on surface ocean $\mathrm{CO}_{2}$ from hourly observations at the Southern Ocean Time Series site south of Australia, Global Biogeochem. Cy., 29, GB004906, doi:10.1002/2014GB004906 2015.

Shiono, M. and Koizumi, I.: Taxonomy of the Thalassiosira trifulta group in late neogene sediments from the northwest Pacific Ocean, Diatom Research, 15, 355-382, 2000.

Siegel, D. A. and Deuser, W. G.: Trajectories of sinking particles in the Sargasso Sea: modeling of statistical funnels above deepocean sediment traps, Deep-Sea Res. Pt. I, 44, 1519-1541, 1997.

Sigman, D. M., Hain, M. P., and Haug, G. H.: The polar ocean and glacial cycles in atmospheric $\mathrm{CO}_{2}$ concentration, Nature, 466, 47-55, 2010.

Smetacek, V., Klaas, C., Menden-Deuer, S., and Rynearson, T. A.: Mesoscale distribution of dominant diatom species relative to the hydrographical field along the Antarctic Polar Front, Deep-Sea Res. Pt. II, 49, 3835-3848, 2002.

Smetacek, V., Assmy, P., and Henjes, J.: The role of grazing in structuring Southern Ocean pelagic ecosystems and biogeochemical cycles, Antarct. Sci., 16, 541-558, 2004.

Smetacek, V., Klaas, C., Strass, V. H., Assmy, P., Montresor, M., Cisewski, B., Savoye, N., Webb, A., d/'Ovidio, F., Arrieta, J. M., Bathmann, U., Bellerby, R., Berg, G. M., Croot, P., Gonzalez, S., Henjes, J., Herndl, G. J., Hoffmann, L. J., Leach, H., Losch, M., Mills, M. M., Neill, C., Peeken, I., Rottgers, R., Sachs, O., Sauter, E., Schmidt, M. M., Schwarz, J., Terbruggen, A., and Wolf-Gladrow, D.: Deep carbon export from a Southern Ocean iron-fertilized diatom bloom, Nature, 487, 313-319, 2012.

Smith Jr, W. O., Keene, N. K., and Comiso, J. C.: Interannual Variability in Estimated Primary Productivity of the Antarctic Marginal Ice Zone, in: Antarctic Ocean and Resources Variability, edited by: Sahrhage, D., Springer Berlin Heidelberg, 131139, 1988.

Smith Jr, W. O., Anderson, R. F., Keith Moore, J., Codispoti, L. A., and Morrison, J. M.: The US Southern Ocean Joint Global Ocean Flux Study: an introduction to AESOPS, Deep-Sea Res. Pt. II, 47, 3073-3093, 2000.

Sokolov, S. and Rintoul, S. R.: Circumpolar structure and distribution of the Antarctic Circumpolar Current fronts: 1. Mean circumpolar paths, J. Geophys. Res.-Oceans, 114, C11018, doi:10.1029/2008JC005108, 2009a.

Sokolov, S. and Rintoul, S. R.: Circumpolar structure and distribution of the Antarctic Circumpolar Current fronts: 2. Variability and relationship to sea surface height, J. Geophys. Res.-Oceans, 114, C11019, doi:10.1029/2008JC005248, 2009 b.

Sokolov, S. and Rintoul, S. R.: Structure of Southern Ocean fronts at $140^{\circ}$ E, J. Mar. Sys., 37, 151-184, 2002. 
Suzuki, H., Sasaki, H., and Fukuchi, M.: Short-term variability in the flux of rapidly sinking particles in the Antarctic marginal ice zone, Polar Biol., 24, 697-705, 2001.

Takahashi, K., Fujitani, N., and Yanada, M.: Long term monitoring of particle fluxes in the Bering Sea and the central subarctic Pacific Ocean, 1990-2000, Progr. Oceanogr., 55, 95-112, 2002.

Takeda, S.: Influence of iron availability on nutrient consumption ratio of diatoms in oceanic waters, Nature, 393, 774-777, 1998.

Taylor, S. R.: Abundance of chemical elements in the continental crust: a new table, Geochim. Cosmochim. Ac., 28, 1273-1285, 1964.

Taylor, S. R. and McLennan, S. M.: The Continental Crust: its Composition 312 pp., 1985.

Thomalla, S. J., Fauchereau, N., Swart, S., and Monteiro, P. M. S.: Regional scale characteristics of the seasonal cycle of chlorophyll in the Southern Ocean, Biogeosciences, 8, 2849-2866, doi:10.5194/bg-8-2849-2011, 2011.

Thunell, R., Pride, C., Ziveri, P., Muller-Karger, F., Sancetta, C., and Murray, D.: Plankton response to physical forcing in the Gulf of California, J. Plankton Res., 18, 2017-2026, 1996.

Tréguer, P. J.: The Southern Ocean silica cycle, Comptes Rendus Geoscience, 346, 279-286, 2014.

Tréguer, P. J. and De La Rocha, C. L.: The World Ocean Silica Cycle, Annu. Rev. Mar. Sci., 5, 477-501, 2013.

Tréguer, P., Nelson, D. M., Van Bennekom, A. J., Demaster, D. J., Quéguiner, B., and Leynaert, A.: The silica budget of the World Ocean: a re-estimate. , Science, 268, 375-379, 1995.

Treppke, U. F., Lange, C. B., and Wefer, G.: Vertical fuxes of diatoms and silicofagellates in the eastern equatorial Atlantic, and their contribution to the sedimentary record, Mar. Micropaleontol., 28, 73-96, 1996.

Trull, T. W., Bray, S. G., Manganini, S. J., Honjo, S., and François, R.: Moored sediment trap measurements of carbon export in the Subantarctic and Polar Frontal zones of the Southern Ocean, south of Australia, J. Geophys. Res.-Oceans, 106, 31489-31509, 2001a.

Trull, T. W., Sedwick, P. N., Griffiths, F. B., and Rintoul, S. R.: Introduction to special section: SAZ Project, J. Geophys. Res.Oceans, 106, 31425-31429, $2001 \mathrm{~b}$.

Trull, T. W., Bray, S. G., Buesseler, K. O., Lamborg, C. H., Manganini, S., Moy, C., and Valdes, J.: In situ measurement of mesopelagic particle sinking rates and the control of carbon transfer to the ocean interior during the Vertical Flux in the Global Ocean (VERTIGO) voyages in the North Pacific, DeepSea Res. Pt. II, 55, 1684-1695, 2008.

Trull, T. W., Schulz, E., Bray, S. G., Pender, L., McLaughlan, D., Tilbrook, B., Rosenberg, M., and Lynch, T.: The Australian Integrated Marine Observing System Southern Ocean Time Series facility, 24-27 May 2010, 1-7, 2010.

Turner, J. T.: Zooplankton fecal pellets, marine snow and sinking phytoplankton blooms, Aquat. Microb. Ecol., 27, 57-102, 2002.

Venables, H. and Moore, C. M.: Phytoplankton and light limitation in the Southern Ocean: Learning from high-nutrient, high-chlorophyll areas, J. Geophys. Res.-Oceans, 115, C02015, doi:10.1029/2009JC005361, 2010.
Venrick, E. L., Lange, C. B., Reid, F. M. H., and Dever, E. P.: Temporal patterns of species composition of siliceous phytoplankton flux in the Santa Barbara Basin, J. Plankton Res., 30, 283-297, 2008.

Waite, A. M. and Nodder, S. D.: The effect of in situ iron addition on the sinking rates and export flux of Southern Ocean diatoms, Deep-Sea Res. Pt. II, 48, 2635-2654, 2001.

Wang, X., Matear, R. J., and Trull, T. W.: Modeling seasonal phosphate export and resupply in the Subantarctic and Polar Frontal zones in the Australian sector of the Southern Ocean, J. Geophys. Res.-Oceans, 106, 31525-31541, 2001.

Westwood, K. J., Brian Griffiths, F., Webb, J. P., and Wright, S. W.: Primary production in the Sub-Antarctic and Polar Frontal Zones south of Tasmania, Australia; SAZ-Sense survey, 2007, Deep-Sea Res. Pt. II, 58, 2162-2178, 2011.

Wright, S. W., Thomas, D. P., Marchant, H. J., Higgins, H. W., Mackey, M. D., and Mackey, D. J.: Analysis of phytoplankton of the Australian sector of the Southern Ocean: comparisons of microscopy and size frequency data with interpretations of pigment HPLC data using the "CHEMTAX"' matrix factorisation program, Mar. Ecol.-Prog. Ser., 144, 285-298, 1996.

Yamanaka, Y. and Tajika, E.: The role of the vertical fluxes of particulate organic matter and calcite in the oceanic carbon cycle: Studies using an ocean biogeochemical general circulation model, Global Biogeochem. Cy., 10, 361-382, 1996.

Yu, E. F., Francois, R., Bacon, M. P., Honjo, S., Fleer, A. P., Manganini, S. J., Rutgers van der Loeff, M. M., and Ittekot, V.: Trapping efficiency of bottom-tethered sediment traps estimated from the intercepted fluxes of 230Th and 231Pa, Deep-Sea Res. Pt. I, 48, 865-889, 2001.

Yuan, X.: High-wind-speed evaluation in the Southern Ocean, J. Geophys. Res.-Atmos., 109, D13101, doi:10.1029/2003JD004179, 2004.

Zentara, S. J. and Kamykowski, D.: Geographic variations in the relationship between silicic acid and nitrate in the South Pacific Ocean, Deep-Sea Res. Pt. I, 28, 455-465, 1981.

Ziveri, P., Broerse, A. T. C., van Hinte, J. E., Westbroek, P., and Honjo, S.: The fate of coccoliths at $48^{\circ} \mathrm{N} 21^{\circ} \mathrm{W}$, Northeastern Atlantic, Deep-Sea Res. Pt. II, 47, 1853-1875, 2000a.

Ziveri, P., Rutten, A., de Lange, G. J., Thomson, J., and Corselli, C.: Present-day coccolith fluxes recorded in central eastern Mediterranean sediment traps and surface sediments, Palaeogeogr. Palaeoecol., 158, 175-195, 2000b.

Ziveri, P., de Bernardi, B., Baumann, K.-H., Stoll, H. M., and Mortyn, P. G.: Sinking of coccolith carbonate and potential contribution to organic carbon ballasting in the deep ocean, DeepSea Res. Pt. II, 54, 659-675, 2007. 